\title{
Deterring Ropers Juveniles: Why Immature Criminal Youth Require the Death Penalty more than Adults - a Law \& Economics Approach
}

\author{
Moin A. Yahya \\ Faculty of Law, University of Alberta \\ Edmonton, AB Canada T6G 2H5 \\ myahya@law.ualberta.ca \\ (780) $492-4445$
}

August 12, 2005

\begin{abstract}
In Roper v. Simmons, the United States Supreme Court declared the death penalty for juveniles unconstitutional. It relied on three reasons, one of which concerns this article, namely the theory that juveniles are less culpable and deterrable than adults. The Court relied on the American Medical Association's amicus brief which purported to show scientifically that juveniles had less developed brains than adults. The Court characterized juveniles as being risk-lovers who highly preferred the present over the future, who loved gains no matter how risky but did not care for losses, and who could not engage in proper cost-benefit analysis, because they underestimated the odds of being caught and convicted. For these three reasons, the Court held that they were not only less deterrable, but that they were also not as culpable as adults. This paper takes issue with this logic, especially the idea that juveniles cannot be deterred. If indeed juveniles are risklovers who cannot engage in cost-benefit analysis, because they prefer the present and misperceive the odds of being caught and punished, then the proper response is to increase the penalties that juveniles face. Using law and economics methodology, I use a simple numerical example to illustrate that juveniles can be deterred no matter how abnormal their preferences are. The deterrence, however, comes at a penalty much higher than what would be required to deter a normal risk-averse individual. Another way to think of juveniles is as demanders of crime who have a very inelastic demand for crime. Thinking of punishment as the price of crime necessitates a very high price to deter juveniles, a price much higher than what adults should face. The Supreme Court, by abolishing the death penalty for juveniles, deprived the States of a valuable tool that they could use to combat juvenile violence. In this paper I also introduce empirical evidence from a series of econometric studies that show that juveniles indeed can be deterred by punishment and to the same degree as adults. Given that juveniles can be deterred, it follows that if adults can be deterred by the death penalty, than so can juveniles. A plethora of econometric studies have emerged showing that the death penalty does reduce homicides and saves lives. The evidence of juveniles' responsiveness to punishment belies the medical claims advanced by opponents of their execution. Furthermore, I argue that the only criteria for culpability is the ability to tell right from wrong, something that even the opponents of juvenile executions conceded juveniles have. I also show that many violent adult criminals suffer from the medical characterizations that typify Roper's juveniles. Hence to rely on medical evidence to decide who should be spared from the death penalty is an absurd proposition, and medical characterizations should be reserved for what medicine does best, namely treatment.
\end{abstract}




\title{
Deterring Ropeis Juveniles: Why Immature Criminal Y outh Require the Death Penalty more than Adults - a Law \& Economics Approach
}

\author{
Moin A. Yahya*
}

\section{Introduction}

In Roper v. Simmons, the United States Supreme Court declared unconstitutional the death penalty for juveniles, a decision that has proven controversial. ${ }^{1}$ The controversy stems mostly from its reliance on foreign law, and from its unprincipled methodology in arriving at the conclusion that a national consensus had developed against juvenile executions. An additional source of controversy, and the subject of this article, is the claim by the Court that juveniles lack the mental capacity to be deterred, and hence capital punishment is ineffective. In this article, I will argue that were this claim true, the logical implication would be precisely the opposite of the Court's holding. My critique will utilize a law and economics approach in evaluating the implications of the majority's opinion.

In Roper, a 17-year-old Missouri teenager decided that he would kill someone, and even bragged about it since he believed (incorrectly at the time) that he would not face the death

\footnotetext{
* Assistant Professor of Law, University of Alberta, Edmonton, AB, Canada. J.D., George Mason University School of Law, 2003. Ph.D. (Economics), University of Toronto, 2000. I would like to thank Robert Chambers, Joanna Harrington, Russ Brown, Craig Lerner, Bruce Johnsen, Sanjeev Anand, John Law, and Ted DeCoste for their valuable and helpful comments. Ryan Clements provided extremely valuable research and editorial assistance, and I am extremely grateful to him. All mistakes are mine.

${ }^{1}$ Roper v. Simmons, 125 S. Ct. 1183 (2005). For reaction to the decision, see James Carlson, Victim's Sister Tries to Live on: She Feels Court Thwarted Justice in Banning Execution of Juveniles, ST. LouIs DISPATCH, July 24, 2005, at B1; Sarah H. Cleveland, Is There Room for the World in Our Courts?, WASH. Post, March 20, 2005, at B04; Christopher Shea, A Scientific Flip-Flop, Boston Globe, March 13, 2005, at D5; Jeff Jacoby, A Phony 'Consensus' on Youthful Killers, Boston GLOBE, March 6, 2005, at D11; Ed Quillen, When Does Adulthood Arrive?, DENVER POST, March 8, 2005, at B07; George F. Will, Injudicious Justice;Regarding Teen Executions, Anthony Kennedy Inexcusably Plays to the Crowd, PITT. Post-Gaz., March 7, 2005, at A15; Opinion, Justices out on a Limb; A Healthy Moral Decision on Juvenile Capital Punishment Arrives via a Path Strewn with Logical and Legal Dangers, PlaIN DEALER, March 4, 2005, at B8. The reaction in the blogosphere was equally unequiviocal. See e.g. Thoughts from the Right, Constitution 101 and Roper v. Simmons, March 4, 2005, available at http://wbloomfield.blogspot.com/2005/03/constitution-101-and-roper-v-simmons.html; The Buck Stops Here, Roper v. Simmons, March 2, 2005, available at http://stuartbuck.blogspot.com/2005/03/roper-v-simmons.html; ProfessorBainbridge, Roper v. Simmons, March 1, 2005, available at http://www.professorbainbridge.com/2005/03/emroper_v_simmo.html; Volokh Conspiracy (Orin Kerr), Roper v. Simmons and Capital Litigation, March 1, 2005, available at http://volokh.com/posts/1109726269.shtml.
} 
penalty because of his age. ${ }^{2}$ Christopher Simmons elaborately schemed with two of his friends to commit murder. He and one of his friends ultimately entered a house at night where a woman was alone. ${ }^{3}$ They bound her and took her to a remote area where she was then murdered.

Simmons was caught, convicted, and sentenced to die. ${ }^{4}$ He appealed unsuccessfully, ${ }^{5}$ but when he brought a state habeus corpus petition his luck turned for the better. ${ }^{6}$ The Missouri Supreme Court commuted his death sentence to life in prison holding that executing juveniles was unconstitutional under the Federal constitution. ${ }^{7}$ Despite an earlier United States Supreme Court ruling permitting the execution of 16 and 17 year olds, ${ }^{8}$ the Missouri Supreme Court reasoned that a national consensus had formed against executing juveniles. Taking their cue from a more recent United States Supreme Court case which prohibited executing the mentally retarded (also on the basis of a national consensus $)^{9}$ the Missouri Supreme Court believed that the Supreme Court would prohibit executing those under the age of 18. The United States Supreme Court indeed affirmed this ruling and in the process, prohibited the execution of juveniles nationally. ${ }^{10}$ Justice Kennedy wrote for the majority consisting of Justices Breyer, Ginsburg, Stevens, and Souter. Justices Scalia, Thomas, and Rehnquist wrote a joint dissent, while Justice O'Connor dissented separately.

${ }^{2} I d$. at 1187

${ }^{3} I d$. at $1187-88$.

${ }^{4} I d$. at $1188-89$

${ }^{5}$ State v. Simmons, 944 S.W.2d 165 (Mo. 1997).

${ }^{6}$ State ex rel. Simmons v. Roper, 112 S.W.3d 397 (Mo. 2003).

${ }^{7} I d$.

${ }^{8}$ Stanford v. Kentucky, 492 U.S. 361 (1989). The United States Supreme Court had earlier ruled that mitigating evidence should be allowed to be introduced as evidence in favor of an accused murderer who was 16 at the time of the murder. Eddings v. Oklahoma, 455 U.S. 104 (1982). In Application of Gault, the Supreme Court held that juveniles had the same rights as adults such as the right to counsel, confrontation and cross-examination of witnesses, and the privilege against self-incrimination. 387 U.S. 1 (1967). In Thompson v. Oklahoma, the execution of 15 year olds was declared unconstitutional. 487 U.S. 815 (1988). For a discussion of the earlier cases and juveniles justice in general, see Barry C. Feld, Juvenile and Criminal Justice System's Responses to Youth Violence, 24 CRIME \& JUST. 189 (1998).

${ }^{9}$ Atkins v. Virigina, 536 U.S. 304 (2002).

${ }^{10}$ Roper, 125 S. Ct. 1183. 
In striking down the death penalty for juveniles, Justice Kennedy relied on three grounds. The first was that a national consensus had formed against juvenile executions. ${ }^{11}$ The second was that juveniles have diminished culpability and maturity rendering them less blameworthy and less deterrable than adults. ${ }^{12}$ The third was the growing international consensus against executing juveniles; a consensus that the majority claimed was not dispositive for the outcome but persuasive. ${ }^{13}$ It is the second ground that concerns this paper. Numerous scholars will no doubt address the first and the third grounds in the years to come. ${ }^{14}$

This article looks at the idea of juvenile culpability and maturity, and whether a diminution of rational decision-making can logically imply a lesser sentence than that which an adult could receive. Diminished reasoning, impulsiveness, and recklessness that characterizes juveniles, the Supreme Court claimed, means that youth are less blameworthy but also undeterrable. If anything, these characteristics, I argue, should lead to the opposite conclusion. If youth cannot be reasoned with, then rather than rewarding them with a diminished punishment, the optimal thing to do is to raise the penalty above what someone who can be reasoned with would need to be deterred. A wise person needs only common sense to refrain from committing crime. No or little punishment is needed to keep such an individual from harming others. A wild animal, on the other hand, can wreak havoc on its surroundings unless it is contained, if necessary, by force. No one would suggest that a wild bear or cat that viciously

\footnotetext{
${ }^{11}$ Id. at $1192-94$.

${ }^{12}$ Id. at $1194-98$

${ }^{13}$ Id. at $1198-1200$.

14 See e.g. Kenneth Anderson, Foreign Law and the U.S. Constitution, 131 PoLICY REV. 33 (2005); Eugene Kontorovich, Disrespecting the 'Opinions of Mankind': International Law in Constitutional Interpretation, 8 GREEN BAG 261 (2005). A few articles have already been posted on the working paper repositories. See e.g. Steven G. Calabresi \& Stephanie D. Zimdahl, The Supreme Court and Foreign Sources of Law: Two Hundred Years of Practice and the Juvenile Death Penalty Decision, available at http://papers.ssrn.com/sol3/papers.cfm?abstract_id=700176; Thomas G. Stacy, Cleaning Up the Eighth Amendment Mess, available at http://papers.ssrn.com/sol3/papers.cfm?abstract_id=703103; Kenneth Anderson, Foreign Law and the U.S. Constitution, available at http://papers.ssrn.com/sol3/papers.cfm?abstract_id=771124; Ernesto J. Sanchez, A Case against Judicial Internationalism, available at http://law.bepress.com/expresso/eps/583.
} 
attacks a human should not be dealt with harshly simply because animals have less capacity to reason and cannot be deterred. If anything, less ability to reason suggests that the punishment should be escalated.

Juvenile crime rates are unacceptably high, and yet the severity of punishments for juveniles has been diminishing. ${ }^{15}$ Figure 1 shows the crime rates for all individuals and juveniles broken down by various age groups. While these numbers dropped over the last decade, the rate for young Americans is still higher than the overall crime rate. Adults are being punished more harshly every day, sometimes with draconian sentences, while juveniles get away with murder. The seriousness and heinousness of their crimes has been getting worse over time. Michael Johnson will soon walk free only seven years after he fatally shot four schoolmates and a teacher as a thirteen year old, along with an eleven year old accomplice. ${ }^{16}$ The two had taken part in what became known as the Columbine Copycat attacks, named after the two juveniles who massacred their classmates and teachers in Columbine Colorado. ${ }^{17}$ Lionel Tate, the twelve year old who killed a six year old and received life in prison only to have the sentence overturned on appeal, just recently decided to order pizza and rob the delivery man by pointing a gun at him. ${ }^{18}$ A fourteen year old boy was recently arrested for allegedly raping a thirteen year old girl in their school bathroom. ${ }^{19}$ Two teenagers are dead, because a sixteen year old decided to fire a pistol in the air outside a house where he was attending a party prompting another teenager in a Cadillac

\footnotetext{
${ }^{15}$ Steven D. Levitt, Juvenile Crime and Punishment, 106 J. POL. ECON. 1156, 1181 (1998).

${ }^{16}$ Melissa Nelson, CONCERN Townspeople Say it is too Soon; Boy who Killed will be Free at 21, THE ADVERTISER, August 12, 2005.

${ }^{17}$ David Washburn, Experts Say Copycat Shooting Just a Matter of When, Where, SAN DIEGO UN.-TRIB., March 23, 2001, at A20.

${ }^{18}$ John-Thor Dahlburg, Young Killer Arrested in Pizza Holdup; Lionel Tate, whose Life Sentence as a Juvenile was Overturned, might Face that Term Again, L.A. TIMES, May 25, 2005, at A13.

${ }^{19}$ Steve Rubenstein, Boy, 14, Hheld after Girl, 13, Reports Rape, SAN FrAN. ChroniCle, May 19, 2005 , at B4.
} 
to fire into the crowd of partygoers. ${ }^{20}$ A sixteen year old girl unhappy with her father's strict discipline hired her seventeen year old boyfriend to fatally stab him. ${ }^{21}$ The stories are endless and the crimes are heinous. The States, therefore, need the maximum flexibility to design their criminal codes to combat juvenile crime.

[Insert figure 1 here]

The outline of this article is as follows. Section I will discuss the Supreme Court's treatment of juvenile's diminished culpability and maturity. Section II will then translate the Supreme Court's characterization of juveniles into economic terms, and then will demonstrate the logical flaw of the Supreme Court's analysis. Section III will canvass the economics literature as it relates to juvenile rationality and responsiveness to incentives both positive and negative with a specific emphasis on whether juveniles can be deterred against committing crimes. Section IV will suggest some thoughts on what the optimal punishment for juveniles should be, while Section V will take a brief look at how our society has changed its perception of juveniles and their responsibilities. The final section will offer some concluding thoughts.

\section{Diminished Culpability: Ropers Juveniles}

\section{The Majority}

Juveniles, the Supreme Court tells us, are different from adults in three respects. The first is that juveniles lack the maturity of adults leading them to sometimes engage in ill-considered and reckless actions and decisions. ${ }^{22}$ The second difference is that "juveniles are more vulnerable or susceptible to negative influences and outside pressures, including peer pressure,"

\footnotetext{
${ }^{20}$ Kathy Jefcoats, Drive-by Shooting Leaves more Tragedy in its Wake, ATLANTA JOUR.-CONST., April 30, 2005, at $1 \mathrm{E}$.

${ }^{21}$ Andrew Tilghman, Suspect will be Tried as an Adult; She is Accused of Hiring Boyfriend to kill her Father when she was 16, HOUST. CHRONICLE, February 12, 2005, at B5.

${ }^{22}$ Roper, 125 S. Ct. at 1195 (citations omitted).
} 
as they have "less control, or less experience with control, over their own environment." 23 The third distinction is that "the character of a juvenile is not as well formed as that of an adult" as the "personality traits of juveniles are more transitory, less fixed." 24 These differences, the Supreme Court concluded, meant that the conduct of juveniles was "not as morally reprehensible as that of an adult." 25 How could they be held to the same standards as adults when they are so vulnerable and lack control over their immediate surroundings, the Supreme Court argued. ${ }^{26}$ Since juveniles are still struggling to define their character at that stage of their life, even heinous crimes committed by juveniles do not indicate a depravity of character as it might if an adult had committed a similar crime. ${ }^{27}$ This diminished culpability of juveniles therefore meant that the "penological justifications" that undergird the death penalty do not apply to juveniles. The two distinct justifications for the death penalty, according to prior Supreme Court jurisprudence, are retribution and deterrence, both of which could not apply to juveniles due to their diminished culpability. $^{28}$

The Supreme Court then stated that diminished culpability meant that society was not justified in imposing the most extreme sanction on juveniles, as "[r]etribution is not proportional if the law's most severe penalty is imposed on one whose culpability or blameworthiness is diminished, to a substantial degree, by reason of youth and immaturity." 29 As to the issue of deterrence, the Supreme Court asserted that there was no evidence that "the death penalty has a significant or even measurable deterrent effect on juveniles." 30 The Court reasoned that the same factors that made juveniles less culpable also meant that juveniles were "less susceptible to

\footnotetext{
${ }^{23} \mathrm{Id}$. at 1195 .

${ }^{24} I d$.

${ }^{25} I d$. (citations omitted).

${ }^{26} \mathrm{Id}$.

${ }^{27} \mathrm{Id}$

${ }^{28} \mathrm{Id}$.

${ }^{29} I d$. at 1196 (citations omitted).

${ }^{30} \mathrm{Id}$.
} 
deterrence." 31 The Court quoted the plurality from an earlier case, ${ }^{32}$ that had outlawed the execution of those 15 years old and under, which observed that "[t]he likelihood that the teenage offender has made the kind of cost-benefit analysis that attaches any weight to the possibility of execution is so remote as to be virtually nonexistent."

The Court conceded that " $[\mathrm{t}] \mathrm{o}$ the extent the juvenile death penalty might have residual deterrent effect, it is worth noting that the punishment of life imprisonment without the possibility of parole is itself a severe sanction, in particular for a young person." ${ }^{\text {,3 }}$ It also admitted that many brutal crimes may be committed by juveniles, and that many juveniles may have sufficient maturity as adults. ${ }^{34}$ The Court rejected, however, the suggestion that juries should be allowed to distinguish between those juvenile offenders who suffer from a lack of maturity and those who are mature and depraved by noting that even expert psychologists find it difficult to differentiate between these two groups. ${ }^{35}$ The Supreme Court concluded that the death penalty for juveniles under 18 years of age would be unconstitutional.

\section{Dueling Briefs and O'Connor's Dissent}

No doubt the majority derived some of its certitude regarding juveniles' characteristics from the respondent's brief (Mr. Simmons), but many of their assertions are contained in the amicus brief filed by the American Medical Association (AMA), as well as another brief filed by the American Psychological Association (APA). Justice O'Connor's dissent, the petitioner's reply brief, as well the amicus brief for the State of Alabama attempted to rebut the claims made by the majority, Mr. Simmons, the AMA, and the APA. Justice O'Connor's dissent, which amplified the rebuttals made by the petitioner and the State of Alabama, took issue with the

\footnotetext{
${ }^{31}$ Id.

${ }^{32}$ Thomson, 487 US at 387.

${ }^{33}$ Roper, 125 S. Ct. at 1196.

${ }^{34}$ Id. at $1196-97$.

${ }^{35} \mathrm{Id}$. at 1197.
} 
Court's analysis of juveniles and whether the differences between them and adults were sufficient to justify outlawing the death penalty.

The AMA's brief made several assertions. Adolescents, the brief argued, behave differently than adults, because their emotions are more volatile, and their brains are not well developed. The AMA conceded that adolescents have the ability to "distinguish right from wrong" and that they do not lack the ability to conduct any cost-benefit analysis. The problem is that they are "risk takers" and they lack the ability to "perceive and weigh risks and benefits accurately." ${ }^{36}$ They focus on "opportunities for gains" rather than "protection against losses."”77 Furthermore, they focus on "short-term consequences," and they "discount future consequences more than adults. ${ }^{38}$ These observations were the results of psychological studies as well as biological differences, most notably the differences in brain structure. ${ }^{39}$ Juveniles rely on different brain regions for certain tasks than adults. ${ }^{40}$ The region that juveniles rely on for information processing is the amygdala, a region that is associated with impulses such as anger and aggression. The region of the brain that adults rely on, the frontal cortex, develops much later in juveniles. ${ }^{41}$ The AMA cited groundbreaking evidence from brain imaging studies that show "that the brain's frontal lobes are still structurally immature well into late adolescence." The prefrontal cortex, which is associated with impulse control, risk assessment, and moral reasoning is "one of the last brain regions to mature."

\footnotetext{
${ }^{36}$ Amicus Brief of American Medical Association available at 2004 WL 1633549, at 5-6 (emphasis in original).

${ }^{37} \mathrm{Id}$.

${ }^{38} \mathrm{Id}$.

${ }^{39}$ Id. at 10-20 (relying heavily on Elizabeth R. Sowell et. al, Mapping Continued Brain Growth and Gray matter Density Reduction in Dorsal Frontal Cortex: Inverse Relationships during Postadolescent Brain maturation, $21 \mathrm{~J}$. NEUROSCIENCE 8819 (2001)).

${ }^{40} I d$. at 11 .

${ }^{41} I d$.

${ }^{42} I d$. at 16 (citations omitted).

${ }^{43} I d$. (citations omitted).
} 
The APA, in its amicus brief, made similar claims. ${ }^{44}$ Adolescents are risk takers by nature, and engage in criminal behavior on a larger scale than adults. ${ }^{45}$ Juveniles have the highest ratio of criminals, as the ratio of criminals in each age group grows steeply until it peaks at age 18 and then drops off. ${ }^{46}$ This statistical observation is true in almost all Western nations. The APA also argued that adolescents are less focused on the future and less likely to appreciate the true costs and benefits of their actions. ${ }^{47}$ This again, the APA claimed, was due to biological reasons. The APA further asserted that juveniles were so psychologically complex that it was impossible to determine whether a particular criminal juvenile was the immature type whose life should be spared or a psychopath who deserved to die. ${ }^{48}$

The petitioner (the State of Missouri) responded to these briefs by disputing the science behind the claims that juveniles were neither culpable nor deterrable. They pointed out that the APA had claimed that juveniles indeed were mature enough to decide whether to have an abortion or not without the need for parental supervision. ${ }^{49}$ Also, relying on competing scientific studies, they suggested that there was little difference between juveniles' cognitive capacities and adults'. As to the risk-taking, the petitioner pointed out that what adults label as risk-taking may be acceptable behavior for juveniles in order to gain experience and learning. ${ }^{50}$ Similarly, conduct that juveniles rationally engage in may be regarded as irrational for adults. The petitioner also rebutted the claims of biological differences between adults and juveniles by

\footnotetext{
${ }^{44}$ Amicus Brief of American Psychological Association available at 2004 WL 1636447.

${ }^{45} \mathrm{Id}$. at 5.

${ }^{46}$ Id. at 5-6.

${ }^{47} \mathrm{Id}$. at 7.

${ }^{48}$ Id. at 20. The respondent's brief made similar claims as the AMA and the APA, although the Court seems to have been influenced by the latter two's briefs. Brief for Respondent available at 2004 WL 1947812.

${ }^{49}$ Reply Brief for Petitioner, available at 2004 WL 2046818, at 9 (citing the APA's amicus brief in Hodgson v. Minnesota, 497 U.S. 417 (1990)).

${ }^{50}$ Id. at 12 (citing L.P. Spear, The Adolescent Brain and Age-related Behavioral Manifestations, 24 NEUROSCI. \& BIOBEHAV. REV. 417, 422 (2000)).
} 
questioning the scientific validity of the studies. The studies were inconclusive and at best speculative, the State of Missouri claimed.

Justice O'Connor also took aim at the majority's claims of why the differences between juveniles and adults justified a ban on their execution. The majority did not explain how the fact that juveniles were less culpable than adults meant that they were not sufficiently culpable to be executed. Also, the fact that the death penalty may be less likely to deter juveniles than adults did not mean that the threat of the death penalty was not an effective threat to prevent some juveniles from committing crimes. She also questioned the validity of comparing juveniles in general with adults in general. Simply because the average youth is less mature than the average adult does not mean that the particular juvenile who committed heinous crime is less culpable. There may be very mature and calculating youth and very immature and naive adults, Justice O’Connor argued.

Justice O'Connor and the petitioner's strategy was to rebut the scientific foundations and assumptions behind the AMA, APA, and majority's claims. This paper takes a slightly different approach. Rather than quibble with the claims made by the AMA, APA, and the majority, I will (in the first part of this article) show that their claims in fact argue for even more stringent penalties than those meted out to adults. Precisely because adolescents are reckless, immature, unable to properly weigh the consequences of their actions, and focus on the present, state governments should be allowed to use the ultimate sanction. In fact, state governments should have the flexibility to devise other punishments that would not ordinarily be administered to adults such as corporal punishment. Later in this article, I will question some of the scientific claims by looking at economic studies that have studied the question of juvenile behavior. 


\section{The Economic Implications of Roper}

The majority (the AMA, and the APA) made three claims regarding juveniles. While not questioning their rationality or ability to engage in cost-benefit analysis per se, they argued that juveniles are incapable of making correct decisions. This is because of the first claim: they are risk lovers. They also, the second claim goes, discount the future by focusing on "opportunities for gains" rather than "protection against losses," they focus on "short-term consequences," and they "discount future consequences more than adults." Finally, they fail to "perceive and weigh risks and benefits accurately."

When viewed from a law and economics lens, these claims imply behavioral consequences for which an economist could generate policy implications. The policy implications of the three claims regarding juveniles would actually be the opposite of the Supreme Court's ruling. If juveniles indeed have these characteristics, then they should be punished more severely than adults. ${ }^{51}$ Juveniles, to use the language of economics, have an inelastic demand for criminal activity, and the price of their crimes, namely the punishment associated with it, must be high (and as immediate) as possible. In this section, I shall deal with each of the three claims, namely, risk-loving, heavy discounting of the future, and incorrect perception of probabilities.

\section{Reckless Youth}

The majority did not advance the claim of irrationality, and in fact, the AMA explicitly denied that juveniles were irrational. The majority and the AMA stressed, however, that

\footnotetext{
${ }^{51}$ So far the one law and economics study that seems to agree with the decision in Roper is Michael E. O'Neill, Irrationality and the Criminal Sanction, 12 SUP. CT. ECON. REV. 139 (2004). For a view that would probably support my views, seeTerrence R. Chorvat \& Kevin McCabe, Neuroeconomics and Rationality, 80 CHI-KenT L. REV. 101 (2005).
} 
juveniles were incapable of correctly assessing the proper costs and benefits of crime due to their love for risk.

The Economics Nobel Laureate Gary Becker pioneered the modern rational actor model of crime (also known as the law and economics of crime). ${ }^{52}$ The model, in its simplest form, posits that since criminals gain from committing crimes, in order to deter them, the state should impose sanction whose expected value exceeds the gains. To take a simplistic example, suppose a criminal gains $\$ 100$ every time he robs a convenience store. Suppose also that the probability of detection and conviction is $10 \%$, the state should then impose a penalty that is at least $\$ 1000$ in magnitude either in the form of a fine or time served in prison for which the opportunity cost to the criminal is $\$ 1000$. This simple model gives the reader a very basic idea of how an economist would approach the question of crime and punishment.

Implicit in the previous example was the assumption that the individual committing the crime was risk-neutral. Risk neutrality means that an individual who is given the choice of a gamble or a certain outcome whose value is equal to the expected value of the gamble will be indifferent between the two. For example, if a gamble paid $\$ 100$ with probability $1 / 2$ and $\$ 0$ also with probability $1 / 2$, the expected value of this gamble would be $1 / 2 \times 100+1 / 2 \times 0=\$ 50$. A riskneutral individual would be indifferent between the two choices. A risk-averse individual, on the

\footnotetext{
${ }^{52}$ Gary S. Becker, Crime and Punishment: An Economic Approach, 76 J. PoL. ECON. 169 (1968). For more on the law and economics approach to crime, see STEVEN SHAVELL, FOUNDATIONS OF ECONOMIC ANALYSIS OF LAW 471 (2004); Robert CoOTER \& ThOMAs Ulen, LAW 502(2003); John Dilulio, Help Wanted: Economists, Crime and Public Policy, 10 J ECON. PERSP. 3 (1996); Isaac Ehrlich, Crime Punishment, and the Market for Offenses, $10 \mathrm{~J}$ ECON. PERSP. 43 (1996); Richard Posner, An Economic Theory of the Criminal Law, 85 ColumBIA L. Rev. 1193 (1985); Michael K. Block \& Robert C. Lind, An Economics Analyis of Crimes Punishable by Imprisonment, 4 J. LEG. STUD. 479 (1975); George J. Stigler, The Optimum Enforcement of Laws, 78 J. POL. ECON. 526 (1970). For a comprehensive survey of the literature, see Erling Eide, Economics of Criminal Behavior in 4 THE ENCYCLOPEDIA OF LAW AND ECONOMICS 345 (Boudewijn Bouckaert \& Gerrit De Geest eds., 2000).
} 
other hand, would prefer the certain value of $\$ 50$ to the gamble that pays $\$ 50$ as an expected outcome. In contrast, a risk-lover prefers the gamble to the certain outcome. ${ }^{53}$

There has been some debate in the economics literature about whether criminals are riskaverse or risk-loving. ${ }^{54}$ Whatever, the case may be, either raising the penalty they face or the probability of detection and conviction can deter both a risk-averse or risk-loving individual. The penalty can be raised either by increasing the fine, amount of time spent in jail, a combination of both, or by imposing the death penalty. Since most punishments are imposed

\footnotetext{
${ }^{53}$ The concept of risk aversion can be derived from a basic economic concept called the diminishing marginal utility of income. One of the basic building blocks of economic models is the utility function. Each individual is assumed to possess a utility function that takes as inputs the consumer's level of consumption of goods and services and generates as an output the level of utility or satisfaction to the consumer. While fictional, nonetheless the utility function serves as a useful tool for understanding economic behavior. Suppose for example, that an individual had a utility function given by $U=\sqrt{x}$, so that the individual received utility equal to the square root of the consumption of quantity $x$ of any good. Hence, if the individual consumed 4 units of apples, she would receive 2 units of satisfaction, and so on. This discussion of consumer demand is a simplified form of standard economic theory. The reader can consult any economics textbook for more details. See e.g. RoBERT PINDYCK \& DANIEL RUBiNFELD, MicRoeCONOMICS 252 ( $5^{\text {th }}$ ed. 2000); BRIAN BINGER \& ELIZABETH HOFFMAN, MicROECONOMICS With CALCulus 315 (1985). For an advanced discussion, see JACK HIRSHLEIFER \& JOHN G. RILEY, THE ANALYTICS OF UNCERTAINTY AND INFORMATION (1992); JACK HIRSHLEIFER, TIME, UNCERTAINTY, AND INFORMATION (1989).

Utility functions are also assumed to exhibit diminishing marginal returns, which means that the more the consumer consumes, the less extra satisfaction she gets from the last unit consumed. While the consumer receives more satisfaction from consuming more units, the marginal increase in satisfaction is decreasing. Hence if the consumer with the utility function given by $U=\sqrt{x}$ ate one apple, she would receive one unit of utility, while if she ate four apples, an increase of three apples, she would only receive two units of utility. Consuming nine apples, an extra five apples, only gives her three units of satisfaction, one extra unit of satisfaction. The increase in satisfaction is known as the marginal utility, and so in the previous example, the marginal utility from consuming the first unit of apples was one, the marginal utility from consuming the next three units was one, and the marginal utility from consuming the next five units was also one.

The idea of deriving utility from consuming goods and services can also be applied to income. Individuals derive utility from their income, because the income can ultimately be used to purchase the goods and services that they wish to consume. The property of diminishing marginal utility can also be applied to income. An individual gains far more satisfaction from making an extra $\$ 10,000$ in income when her initial income was $\$ 10,000$ then when her initial income was $\$ 1$ million. Given that an individual gains less satisfaction from the extra income at higher levels of income, the converse is also true, i.e. such an individual will not lose as much satisfaction if they lost $\$ 10,000$ in income when their initial income was $\$ 1$ million as opposed to when their initial income was $\$ 10,000$. This should suggest to the reader that an individual who is offered the opportunity to participate in lottery that pays $\$ 10,000$ with probability $1 / 2$, and $\$ 0$ with probability $1 / 2$, then this individual is more likely to partake in the lottery if his income is $\$ 1$ million than if his income were $\$ 10,000$. This simple example can be used to motivate the idea of risk aversion. The lottery represents the risk and uncertainty that faces the consumer.

A risk-loving individual, on the other hand, derives more utility from consumption or income as the units consumed increase. Such an individual's utility can be represented by a function such as $U=x^{2}$.

${ }^{54}$ See Michael K. Block \& Vernon E. Gerety, Some Experimental Evidence on the Differences between Student and Prisoner Reactions to Monetary Penalties and Risk, 24 J. LEG. STUD. 123 (1995); Jeffery grogger, Certainty vs. Severity of Punishment, 29 ECON. INQUIRY 297 (1991).
} 
many months or years after the crime was committed, this causes criminals to discount the cost of their crime. Hence speeding up their punishment by limiting appeals or by expediting trials and appeals for the criminally accused would also raise the penalty as perceived by the criminal. $^{55}$

Gary Becker had speculated that criminals are risk loving. ${ }^{56}$ In his mathematical model of criminal behavior he assumed that when a criminal commits a crime, it would net him income $Y$ if he is not caught and income $Y-f$ (where $f$ is the fine) if caught. The criminal will be caught with probability $p$, and so the expected utility for the criminal is $(1-p) U(Y-f)+p U(Y)$, where $U$ is the utility function of the criminal. ${ }^{57}$ If the criminal is risk averse, then the utility function will be concave which means that the criminal displays a diminishing marginal utility of income. Such a criminal will be deterred more by an increase in the penalty than the increase in probability of detection; a $1 \%$ increase in penalty will deter more than a $1 \%$ increase in probability of apprehension and conviction. The opposite is true if the criminal is risk-loving; a $1 \%$ increase in probability of detection will deter more than a corresponding increase in the penalty. In both cases, though, increasing the penalty will deter the criminal.

To see this, a numerical example can be helpful. Suppose an individual is risk-averse. This individual will have a utility function that could be represented by $U=\sqrt{x}$, where $x$ is the

\footnotetext{
${ }^{55}$ Harold J. Brumm and Dale O. Cloninger, Perceived Risk of Punishment and the Commission of Homicides: A Covariance Structure Analysis, 31 J. ECON. BEHAVIOR \& ORG. 1 (1996); Maynard L. Erickson, Jack P. Gibbs, \& Gary F. Jensen, The Deterrence Doctrine and the Perceived Certainty of Legal Punishments, 42 AM. SoC. REv. 305 (1977).

${ }_{56}$ Becker, supra note 52 at 178. But see William M. Brown \& Morgan O. Reynolds, Crime and "Punishment": Risk Implications, 6 J. ECON. THEORY 508 (1973) (taking issue with Becker's results on the grounds that Becker's results is specific to his mathematical formulation and cannot necessarily be generalized). See also Raymond Dacey, The S-Shaped Utility Function, 135 SYNTHESE 243 (2003) (showing that alternative specification can explain why criminals respond more to a change in the probability of detection than the severity of punishment); William S. Neilson and Harold Winter, On Criminal's Risk Attitudes, 55 Econ. Letters 97 (1997) (showing that criminals can respond more to a change in the probability of detection than the severity of punishment and still be risk-averse).

${ }^{57}$ See note 53 supra for details on utility functions.
} 
income the individual receives. ${ }^{58}$ Suppose the individual has an annual income of $\$ 10,000$. This income does not depend on whether he commits a crime or not. Now suppose that he could commit a crime that will give him actual or psychic income of $\$ 1000$ per year. If he is caught and convicted, he will pay a fine of $f$ (this could also be thought of as time in jail where he loses income equal to $f$ ). The probability of being caught and convicted in this example is $20 \%$. In this case, the individual compares the expected utility of committing the crime (which entails a $20 \%$ chance of being caught and having income $10,000-f$ or an $80 \%$ chance of having an income of $\$ 11,000$ ) with the certain utility of not committing the crime (and hence having an income of $\$ 10,000)$. This means that the individual will commit the crime if $0.8 \sqrt{11,000}+0.2 \sqrt{10,000-f}>\sqrt{10,000}$. To see the impact of increasing $f$ on the decision whether to commit the crime or not, I have plotted the left hand side of the previous expression in figure 2. The dotted line in figure 1 is the utility of no crime or $\sqrt{10,000}$. The reader can see that when the fine is less than $\$ 3500$, a crime will be committed and when the fine rises above that, this individual will not carry out any crime.

\section{[Insert figure 2 here]}

Now suppose that the individual is risk-loving. In this case, we can model his utility function as $U=x^{2} .{ }^{59}$ Suppose that the income levels and probability of detection are also the same as in the previous example. Then this individual will commit the crime if

\footnotetext{
${ }^{58}$ To see that this individual is indeed risk-averse, consider two choices that this person could face: a gamble where the outcome is either $\$ 100$ or $\$ 0$ with equal probabilities or a certain amount of $\$ 50$, which is equal to expected value of the gamble. The utility of the certain amount is equal to $U=\sqrt{50}=7.07$. The expected utility of the gamble is $0.5 \sqrt{100}+0.5 \sqrt{0}=5$, and therefore, this individual will prefer the certain amount to the gamble. This is the definition of a risk-averse person.

${ }^{59}$ To see that this individual is indeed risk-loving, consider the two choices that were intrdocued in footnote 58 supra. The utility of the certain amount is equal to $U=50^{2}=2500$. The expected utility of the gamble is $0.5(100)^{2}+0.5(0)^{2}=5,000$, and therefore, this individual will prefer the gamble to the certain outcome. This is the definition of a risk-loving person.
} 
$0.8(11,000)^{2}+0.2(10,000-f)^{2}>(10,000)^{2}$. Figure 3 shows that for fines less than $\$ 6,000$, the individual will carry out his crime, while above $\$ 6,000$ he will desist. Two things should be noted: there exists a penalty that will deter this individual, but the penalty required to deter was about $70 \%$ higher than what was needed to deter the risk-averse individual.

[Insert figure 3 here]

If juveniles are indeed risk loving, then this means that while the state would be better served devoting resources to detection and successful prosecutions, increasing the penalty will also deter them. Moreover, the state will need to increase the penalty by a substantially larger amount than it would have to if it wanted to deter risk-averse individuals. Given the Supreme Court's assumption was that adults are typically more risk-averse than juveniles, the implication of their logic is that juvenile penalties should be much higher than those associated with adults.

If juveniles are indeed risk-lovers, the Supreme Court, by removing the ultimate sanction from the states' arsenal of punishments, has unwittingly lowered the deterrence measures available to states combating youth crime. States will now have to devote more resources to policing, and prosecutions, thereby diverting resources that could have been used to combat adult crime.

Another way to understand the proposition that even risk-lovers can be deterred is to think of crime as a commodity that criminals consume. Criminals, therefore, will demand crime just as they demand any other commodity. ${ }^{60}$ An apple is demanded because of its good taste and its health qualities. Similarly, criminals demand crime for the real and psychic income that it provides. The price charged for a commodity determines the amount that consumers will purchase. A rise in the price will ensure that less of the good is purchased, and the converse is

\footnotetext{
${ }^{60}$ Most criminal economic studies analyzing crime model crime as a product that is supplied by the criminal, but the analysis here is equivalent to these other studies. See e.g. Becker, supra note 52; Ehrlich supra note 52.
} 
true. Some commodities have a very strong demand, and its consumers will be not deterred by a slight increase in price. We call the demand for these commodities inelastic. A $1 \%$ increase in price will result in less than a $1 \%$ decrease in quantity demanded by the consumers. Examples of such commodities include necessary food items, cigarettes (especially for heavy smokers), electricity, and gasoline. These are goods that we all must consume a certain amount of to survive and live. They may also be commodities that are addictive in nature (such as tobacco and dugs), and hence the consumer will be willing to pay whatever price to purchase them. These inelastically demanded goods, however, will see a drop in the amount demanded as at some price level (usually quite high), consumers will begin to cut back on their consumption. Consider figure 4. In it, D1 and D2 represent the demand for two goods. The demand curve D1 is inelastic as it is very steep, while D2 is not as steep and represents a more elastic demand. At the price of $\$ 15$, demand curve D1 shows that for this commodity, the quantity consumed will be 15, while for demand curve D2, 200 units will be demanded. When the price increases to $\$ 90$ the units consumed for both demand curves drop to 10 . For D1, there is a one third drop in the units consumed, whereas for the same price increase there is a $95 \%$ drop in units consumed for D2. Clearly, the commodity whose demand is represented by D2 is more sensitive (and hence elastic) to price fluctuations than the commodity represented by D2.

$$
\text { [Insert figure } 4 \text { here] }
$$

The demand for crime can also be modeled as a commodity. If in fact juveniles are risklovers who do not estimate the odds of being caught, convicted, and punished properly, and who prefer gains to losses, then their demand for crime can be described as highly inelastic. This would imply that the proper price of crime should be set much higher than the price set for adults whose demand for crime is more elastic. 
At the prevailing punishment severity for juveniles, social scientists and the courts may be tempted to say that they are undeterrable, but what may be observed in fact, since juveniles are typically not punished as severely as adults, is that their demand for crime is still high. Juvenile punishment has been declining in severity over the last two decades, and this may explain the growing relative juvenile crime rate. ${ }^{61}$ Rather than further decreasing the punishment for juvenile crimes, the solution is to increase the penalties for youth crime. The decision in Roper clearly has removed that option from policy makers.

\section{Lovers of Gains and the Present; Eschewers of Losses and the Future}

Another claim was that juveniles discount the future much more heavily than adults, and that they have a love for gains and do not care about losses. These claims also do not defeat the case for the juvenile death penalty; rather, they bolster it. I will discuss the question of discounting first and then the question of asymmetric preferences over gains and losses.

The idea of discounting is intuitive. All things being equal, we would prefer the present to the future. If any individual were offered the choice of one apple today versus one apple tomorrow or next years, surely the choice would be the apple today. But if the choice were one apple today versus two apples tomorrow, the answer might be different. For some quantity of apples, an individual will choose to forgo consumption today in favor of waiting for the extra consumption tomorrow. ${ }^{62}$ Suppose an individual chose to accept $\$ 1.25$ next year instead of $\$ 1$ today, then we could infer that this individual placed $25 \%$ less value on consumption next year than today. Economists call the $25 \%$, the "discount rate." This is the rate by which the individual devalues the future as compared to the present. The value of the future today is called

\footnotetext{
${ }^{61}$ Levitt, supra note 15.

${ }^{62}$ The idea of discounting is a well known proposition in Economics and Finance. For a general introduction, see Zvi Bodie \& Robert C. Merton, Finance 101-42 (2000). See also Shane Fredrick, George F. Loewestein, \& Ted O’Donoghue, Time Discounting and Time Preference: A Critical Review, 90 J. EcON. LIT. 351 (2002).
} 
"present value." If an individual's discount rate is very high, then even high amounts in the future will be valued much less today. For example, consider two individuals, one of whom has a discount rate of $5 \%$ whereas the second has a discount rate of $10 \%$. Suppose they both are faced with the choice of accepting \$100 today or \$107 next year. The first individual discounts the future at $5 \%$, and hence values $\$ 107$ next year today at $\frac{107}{1.05}=\$ 102$, which implies that he will prefer to wait over accepting the $\$ 100$ today. The present value to this individual of $\$ 107$ is $\$ 102$. The second individual, on the other hand, will accept the $\$ 100$ today, as the present value of $\$ 107$ is $\frac{107}{1.10}=\$ 97$. Thus the higher the discount rate, the more impatient the individual is. Higher discount rates lead to lower present values and a greater desire for present consumption. Just as individuals can discount future gains, they can also discount future losses. A criminal who will face a fine of $\$ 100$ next year will only compare the present value of the fine with the payoff from committing the crime today. Hence a crime that pays $\$ 100$ today will require a fine of at least $\$ 100 \times(1+r)$, where $r$ is the discount rate of the individual. If $r=5 \%$, for example, then the fine would have to be equal to at least $\$ 105$ to make the crime an unattractive proposition. Suppose, however, that the individual's discount rate was $10 \%$. In this case, the penalty would have to be at least $\$ 110$. The higher the discount, i.e. the more impatient the individual, the higher the punishment has to be. In the case of juveniles, their discount rates, the Supreme Court and the AMA tells us, are very high. But as I have demonstrated above, the solution is not to lower the punishment, but rather, to raise it.

Recall the argument that juveniles are impulsive and do not consider the cost of punishment no matter how high the cost in the future. Impulsiveness is actually not a criticism unique to juveniles. In fact, psychologists and economists have long observed the idea that 
people irrationally prefer small present gains to larger future gains. For example, it has been observed that many would prefer $\$ 50$ today over $\$ 100$ a year from now, and yet when presented with the choice of $\$ 50$ ten years from now versus $\$ 100$ in eleven, most prefer the $\$ 100$ in eleven years. This inconsistency has led many economists to posit that our discount rates are not constant; instead, we engage in "hyperbolic discounting."63 Our discount rates, economists argue, are extremely high when we are concerned about the immediate present, whereas our discount rates are much lower when the choice is between events in the future. Hyperbolic discounting has been cited as an explanation for why many procrastinate when they should be filling out their taxes, quit smoking, or schedule a medical checkup, ${ }^{64}$ why food-stamp recipients eat 10-15 per cent more at the beginning of the month than the end of the month, ${ }^{65}$ and why people may not save enough for retirement as they prefer present consumption over having income at retirement. ${ }^{66}$ Whether hyperbolic discounting explains much of our hastiness, ${ }^{67}$ what the reader should take from this is that any claim that juveniles are impulsive is an argument that could be made for all members of society juvenile and adult. At best what distinguishes adults and juveniles might be the level of impatience, a point that Justice O'Connor repeatedly made regarding the immaturity of juveniles. If indeed juveniles are hasty and impulsive, the same is true of adults. Yet, no one would or could claim to excuse adults from any moral culpability if they committed a heinous crime. Pedophiles, for examples, are characterized, according to many

\footnotetext{
${ }^{63}$ A comprehensive introduction to the subject of hyperbolic discounting can be found in GEORGE AINSLIE, BREAKDOWN OF WILl (2001); PICOECONOMICS: STUDIES IN RATIONALITY AND SOCIAL ChANGE (1992).

${ }^{64}$ Ted o'Donoghue \& Matthew Rabin, Choice and Procrastination, 116 Q.J. ECON. 121 (2001).

${ }^{65}$ Jesse M. Shapiro, Is There a Daily Discount Rate? Evidence from the Food Stamp Nutrition Cycle, 89 J. PUB. ECON. 303 (2005).

${ }^{66}$ Peter Diamond \& Botond Koszegi, Quasi-Hyperbolic Discounting and Retirement, Is There a Daily Discount Rate? Evidence from the Food Stamp Nutrition Cycle, 87 J. PUB. ECON. 1839 (2003).

${ }^{67}$ For a skeptical view, see Ariel Rubinstein, "Economics and Psychology"? The Case of Hyperbolic Discounting, 44 INT. ECON. REV. 1207 (2003) (arguing that much of the observed anomalies in behavior cannot be adequately explained by hyperbolic discounting).
} 
psychiatrists, by impulse control disorders, ${ }^{68}$ and yet no one would claim that they should be less morally culpable than regular adults. ${ }^{69}$ In fact, the United States Supreme Court has upheld civil commitments of sexual offenders when their sentences have been served, because of the fear that such offenders can easily re-offend. ${ }^{70}$ Juveniles should therefore be no less culpable simply because they are impulsive, and the states should be allowed to set punishments high enough to deter them.

If a higher discount rate is what is needed to spare the lives of juvenile murderers, then surely adult criminals who have similar discount rates should also be spared. Adults do not have homogenous discount rates, for some of us are savers and some of us are borrowers. At the prevailing market interest rates, some individuals prefer to lend money to the bank, while others borrow. In fact, the variance between personal discount rates can be as high as 30 per cent, ${ }^{71}$ and one study found personal discount rates varied from 17 to $243 \% .^{72}$ One study found that rich white educated families had much lower discount rates than poor non-white non-educated families. It would be a curious result if non-educated non-white poor borrowers were spared the death penalty for a murder, while a rich white saving individual could be executed for the same crime. But if the logic of Roper were to apply, that would be exactly the type of result we should expect.

\footnotetext{
${ }^{68}$ Lisa J. Cohen \& Igor I. Galynker, Clinical Features of Pedophilia and Implications for Treatment, 8 J. PSYCHIATRIC PRACTICE 276 (2002) (citing Dan J. Stein et. Al, Sexual Disorders not Otherwise Specified: Compulsive, Addictive or Impuslive, 5 CNS SPECTRUMS: THE INT. J. NEUROPSYCHIATRIC MED. 60 (2000)). AM. ECON. REV. 33 (2001) (finding personal discount rates among members of the military to ranger between zero and 30 per cent).

${ }^{72}$ Id. at 36 (citing Henry Ruderman, Mark Levine, \& James McMahon, Energy-Efficiency Choice in the Purchase of Residential Appliances, in ENERGy EFFICIENCY: PERSPECTIVES ON INDIVIDUAL BEHAVIOR (Willett Kempton \& Max Neiman eds., 1986). See also Uri Benzion, Ammon Rapoport, \& Joseph Yagil, Discount Rates Inferred from Decisions: An Experimental Study, 35 MGMT SCI. 270 (1989); Dermot Gatley, Individual Discount Rates and the Purchase and Utilization of Energy-Using Durables: Comment, 11 BELL J. ECON. 373 (1980); Jerry A. Hausmann, Individual Discount Rates and the Purchase and Utilization of Energy-Using Durables, 10 BELL J. ECON. 33 (1979).
} 
As to the claim that they prefer gains to losses, the response is similar. The idea that there can be asymmetric preferences over gains and losses is not new to economists. Two psychologists/economists, Kahneman and Tversky pioneered the area of behavioral economics. In their seminal paper and subsequent work, they showed that people have asymmetric responses to risk depending on whether the risk is beneficial or detrimental. ${ }^{73}$ For example, many people are risk averse when it comes to gains and risk loving when it comes to losses. The reasoning behind this is what is called "loss-aversion." Suppose that an individual was offered the choice between a lottery that pays $\$ 0$ or $\$ 100$ with equal probabilities or a certain sum of $\$ 50$. I established earlier that a risk-averse individual would prefer the certain sum of $\$ 50$ to the lottery. Now suppose that the individual was faced with the choice of accepting a certain loss of $\$ 50$ or the chance to lose $\$ 100$ or $\$ 0$ with equal probabilities. A rational risk-averse individual should take the certain loss of $\$ 50$. Many individuals, however, will choose the lottery. The reasoning is as follows: since the individual is so averse to losing, the idea of losing $\$ 50$ with certainty seems quite stressful. The lottery, on the other hand, does offer a chance to not lose any money at all. Hence, the individual will choose the lottery, so that he can have some chance of avoiding the loss altogether. ${ }^{74}$

Figure 5(a) displays graphically the utility function of a risk-averse individual, while figure 5(b) shows a utility function for a risk-lover. Utility is on the vertical axis, while income is on the horizontal axis. The reader can see that I have chosen $\$ 100$ as the initial income point.

\footnotetext{
${ }^{73}$ Daniel Kahneman \& Amos Tversky, Prospect Theory: An Analysis of Decision Under Risk, 47 ECONOMETRICA 263 (1979); Rational Choice and the Framing of Decisions, 9 J. BusINESS 251 (1986); Loss Aversion in Riskless Choice: A Reference Dependant Model, 106 Q. J. ECON. 1039 (1991); Advances in Prospect Theory: Cumulative Representation of Uncertainty, 5 J. RISK \& UNCERTAINTY 297 (1992). See also Daniel Kahneman, Maps of Bounded Rationality: Psychology for Behaviorla Economics, 93 AM. ECON. REV. 1449 (2003); Owen D. Jone, Time Shifted Rationality and the Law of Law's Leverage: Behavioral Economics Meets Behavioral Biology, 95 Nw. U. L. REV. 1141 (2001); Haim Levy \& Zvi Weiner, 16 J. RISK \& UNCERTAINTY 147 (1998).

${ }^{74}$ Robert Ellickson, Bringing Culture and Human Frailty to Rational Actors: A Critique of Classical Law and Economics, 65 CHI.-KENT L. REV. 23, 35-40 (1989).
} 
The utility of $\$ 150$ of certain income is higher than the expected utility from either $\$ 100$ or $\$ 200$. Similarly, the utility of $\$ 50$ with certainty (i.e. a sure loss of $\$ 50$ ) is higher than the expected loss of $\$ 100$ or $\$ 0$ with equal probability. The risk-lover prefers the lottery in both instances.

[Insert figure 5 here]

Figure 6 shows the utility function of the individual who is risk-averse to gains but riskloving over losses. ${ }^{75}$ The utility function looks like the letter $\mathrm{S}$, and hence is called an S-shaped utility function. The individual prefers to have $\$ 150$ income rather than take his chances with the lottery, but will choose the lottery over losing $\$ 50$ with certainty.

[Insert figure 6 here]

Were juveniles to have S-shaped utility functions, the analysis would be simple. Since punishment represents a loss and crime gives some gain, an individual who has an S-shaped utility function will actually commit less crime than even a normally risk-averse individual. The potential loss from a fine or jail (or death) would scare most people away from committing a crime, and the potential gain would not be worth the loss. An example using previously noted parameters would be instructive. ${ }^{76}$ Suppose the individual has an initial income of $\$ 10,000$ and will gain $\$ 1000$ from committing a crime. If he is caught, which will occur with probability 0.2 , the fine will be $f$. Now suppose that for gains above $\$ 10,000$, this individual's utility function is risk-averse but below the initial income it is risk-loving. The expected utility can be represented by $U=0.8 \times \sqrt{11,000}+0.2 \times \frac{(10,000-f)^{2}}{1,000,000}$. In this case, a fine of only $\$ 1,000$ is needed to deter, which is well below the $\$ 3,500$ that even a risk-averse individual would require to be deterred.

\footnotetext{
${ }^{75}$ Ellickson supra note 74. See also Dacey, supra note 56.

${ }^{76}$ See text associated with notes 58 supra.
} 
Juveniles, however, according to the AMA have a reverse-S-shaped utility curve, since they are not loss-averse, but gain loving. Their utility function would be represented by figure $7 .^{77}$

\section{[Insert figure 7 here]}

In figure 7 , the individual prefers the lottery when a gain is involved, but prefers the certain loss to the chance of avoiding it. Crime is typically random in its payoff. While the average robbery nets a thief only $\$ 3000,{ }^{78}$ for example, there is always the potential for the million dollar heist. The fact that there is a chance of jail does not seem to matter. Since the juvenile is not loss-averse, the thought of losing does not matter. An example is instructive. Suppose the individual has an initial income of $\$ 10,000$ and will gain $\$ 1000$ from committing a crime. If he is caught, which will occur with probability 0.2 , the fine will be $f$. Now suppose that for gains above $\$ 10,000$, this individual's utility function is risk loving but below the initial income it is risk-averse. The expected utility can be represented by $U=0.8 \times \frac{(11,000)^{2}}{1,000,000}+0.2 \times \sqrt{10,000-f}$. Here the fine would have to be equal to 9800 to keep this individual from committing the crime. This is quite a steep fine compared to earlier results, and suggests two things. First, such an individual is determined to commit a crime unless the punishment is steep; and second, the punishment must be steep to deter. Note, in contrast, that if the juvenile possesses a normal S-shaped curve, the fine would only have to be set at $\$ 1,000$ or $\$ 3,500$ were the juvenile risk-averse. Even the risk-loving juvenile only required a fine of $\$ 6,000$. Removing the option to impose steep penalties including the death penalty from the states will only result in more juveniles engaging in crime. Obviously for Mr. Simmons, as he

\footnotetext{
${ }^{77}$ The evidence from the experimental economics literature supports this claim. William T. Harbaugh, Kate Krause, \& Lise Vesterlund, Risk Attitudes of Children and Adults: Choices Over Small and Large Probability Gains and Losses, 5 EXPERIMENTAL ECON. 53 (2002).

${ }^{78}$ Warren St. John, Today's Bank Robber might Look Like a Neighbor, N.Y. TiMES, July 3, 2004, at A1.
} 
contemplated his crimes, only death was the proper deterrent, since he thought (incorrectly at the time) that juveniles could not be executed.

\section{Misperceivers of Probabilities}

The last argument for why juveniles cannot be deterred is that juveniles cannot "perceive and weigh risks and benefits accurately." This is another observation that psychologists and economists have made regarding all individuals. Again, Kahneman and Tversky observed this many years ago. They noticed that people over-estimate small probability events and underestimate large probability events. In the case of a juvenile deciding whether to commit a crime, the probability in question is the probability of detection and conviction. According to the research, the probability of detection and conviction for many crimes is small. ${ }^{79}$ If juveniles behaved as Kahneman and Tversky's adults and over-estimated the probability of detection, then this would indeed be nirvana for law enforcement authorities. ${ }^{80}$ By over-estimating the probability of being caught and convicted, the state can deter a juvenile with a smaller fine or jail penalty. On the other hand, if juveniles actually behaved differently from adults in that they underestimated small probability events, so that they were even more myopic about the odds of escaping with their crimes, then the implication would be that harsher penalties would be needed. Consider two risk loving individuals similar to the individual analyzed above. ${ }^{81}$ The first individual is a juvenile who correctly perceives the probability of detection at $20 \%$, while the second individual is a juvenile who believes that the probability of detection is only $17.5 \%$. The difference in the perceived odds of detection is small, but the extra penalty needed to deter is

\footnotetext{
${ }^{79}$ Ehrlich, supra note 52, (in 1991, the probability of imprisonment for murder was $28.4 \%$, for rape $5.2 \%$, for robbery $3.6 \%$, aggravated assault $1.7 \%$, burglary $1 \%$, larceny $0.8 \%$, and for auto theft $0.4 \%$ ).

${ }^{80}$ William S. Neilson, Probability Transformations in the Study of Behavior Toward Risk, 135 SYNTHESE 171, 184 (2003) (arguing that even though the probability of being audited for tax evasion is less than $2 \%$, individuals are honest in their tax reporting because they over-estimate the odds of being audited).

${ }^{81}$ See text associated with note 59 supra.
} 
very high. The first individual requires a fine of $\$ 6,000$ to be deterred, while the second individual requires a fine of $\$ 9,100$. If indeed juveniles consider the odds of detection to be even lower than they are, the implications are clear once again: harsher penalties are needed.

In all the scenarios presented above, the implication has always been the same. In order to deter juveniles whose behavioral characteristics are portrayed in Roper, more severe punishments are needed. Now that the death penalty is no longer available to the states, juveniles will have less to fear when committing their crimes.

\section{Will Higher Penalties Really Deter? A Theoretic Detour}

Many skeptics doubt that juveniles can be deterred, ${ }^{82}$ so much so that some have called juvenile criminals "super-predators." Many non-econometric studies, particularly those done by sociologists, claim to show that punishment does not deter crime. Their studies usually involve juvenile criminals who are either interviewed or followed after their release from prison. Those interviewed claim that they will re-offend regardless of what punishment awaits them, while those followed usually re-offend after being released. This, the skeptics claims, is proof of the lack of deterrence. I will present the econometric evidence to the contrary in the next section, but in this sub-section, I wish to focus on the basics of deterrence.

Consider three youth who differ in their level of risk-tolerance. The first is risk-averse, whose utility function is given by $U=\sqrt{x}$, the second individual is risk-loving and has a utility function given by $U=x^{1.5}$, while the third is also risk-loving but loves risk even more and has

\footnotetext{
${ }^{82}$ The most comprehensive study is ANNE L. SCHNEIDER, DETERRENCE AND JuVENILE CRIME (1989). See also Lee Michael Johnson, Ronald L. Simons, \& Rand D. Conger, Criminal Justice System Involvement ad Continuity of Youth Crime: A Longitudinal Analysis, 36 YOUTH \& SOCIETY 2 (2004); Anne L. Schneider and Laurie Ervin, Specific Deterrence, Rational Choice, and Decision Heuristics: Applications in Juvenile Justice, 71 Soc. ScI. Q. 585 (1990). For a general skeptical view of any deterrence effect of punishment see Paul H, Robinson\& John M. Darley, Does Criminal Law Deter? A Behavioral Science Investigation, 24 OXFORD J. LEG. STUD. 173 (2004); The Role of Deterrence in the Formulation of Criminal Law Rules: At its Worst when doing its Best, 91 GEO. L.J. 949 (2003).
} 
the utility function $U=x^{2}$. Suppose all individuals have an initial income of $\$ 10,000$, gain $\$ 1000$ from committing crime, will be caught and convicted with probability $20 \%$, and will face a fine $f$. The fine needed to deter the first individual is $\$ 3,500$ (as shown above), for the second individual is $\$ 4,800$, and for the third individual is $\$ 6,000$ (also shown above). This shows that the more risk-loving the individual, the higher the fine has to be to keep him from crime.

Suppose now that the maximum fine is $\$ 5000$. The first two individuals will not commit any crimes, but the third person will. Now suppose the third person were apprehended and convicted. When he is interviewed or followed after release from prison, unless the maximum fine has been raised, he will probably re-offend again. To say that punishment does not deter is false. It did deter the first and second individual, but not the third. The solution would be raising the penalty.

Suppose now that the maximum penalty is raised to $\$ 5,500$. In this case, the first and second individual will still not offend. The third individual will continue to commit his crime, as the fine has not been raised high enough. This does not evidence the lack of a deterrent effect; rather it evidences penalties that are not high enough. ${ }^{83}$ So far, I have shown in my analysis that juveniles need to face high penalties to deter them. If we, in reality, observe that penalties so far have not had that effect, then this is not necessarily evidence of irrationally and undeterrability. On the contrary, if anything, this is evidence that society has not set the penalties high enough. Whether this is in fact what we observe is the subject of the next section where I will present the results of empirical studies regarding juvenile crime and deterrence.

\footnotetext{
${ }^{83}$ It could also, of course, evidence low probabilities of detection and conviction.
} 


\section{So are Juveniles Rational Criminals? The Empirical Evidence}

In this section, I will introduce evidence of juvenile rationality and deterrability. The evidence comes not from the medical or psychological literature but from economic studies. In the first sub-section, I will describe the direct evidence on whether juveniles can be deterred from committing crimes, while in the second sub-section, I will look at other evidence regarding juvenile rationality and economic decision-making. I will also look at other groups that have been characterized as undeterrable such as psychotics, drug addicts, and the mentally ill.

\section{The Direct Evidence}

Before investigating whether punishment deters juveniles from committing crimes, I will introduce some evidence that children are rational in a very basic way. ${ }^{84}$ The most basic test of rationality among economists is to see if an individual satisfies the assumption of transitivity. The basic statement of the assumption of transitivity is as follows: A is preferred over B, B is preferred over $\mathrm{C}$, this means that $\mathrm{A}$ is preferred over $\mathrm{C}$. In other words, if an individual is presented the option of choosing between commodity A and B, and the individual chooses A, when presented with the choice between $\mathrm{B}$ and $\mathrm{C}$, and the individual chooses $\mathrm{B}$, then when presented with the choice of $\mathrm{A}$ and $\mathrm{C}$, the individual should choose $\mathrm{A}$. Three economists Harbaugh, Krause, and Berry investigated whether children were rational using transitivity as a measure of rationality. ${ }^{85}$ They conducted a simple experiment where they asked several groups of children and adults to choose between a variety of choices. They conducted their experiments on a group of second graders whose average age was 7 years, sixth graders whose average age was 11 , and a group of undergraduates whose average age was 21 . They found that in all age

\footnotetext{
${ }^{84}$ Gary Becker has argued that even if individuals are not rational, their aggregated behavior will still be rational. Gary S. Becker, Irrational Behavior and Economic Theory, 70 J. POL. ECON. 1 (1962).

${ }^{85}$ William Harbaugh, Kate Krause, \& Timothy R. Berry, GARP for Kids: On the Development of Rational Choice Behavior, 91 AM. ECON. REV. 1539 (2001).
} 
categories a portion of the group violated the transitivity property, and hence could be classified as irrational. The 7 year olds for the most part did behave rationally; however, there was a portion of them who did not. The 11 year olds and 21 year olds behaved rationally, and the proportion of rationality increased. What was revealing, though, was that while the proportion of children who displayed irrational behavior dropped noticeably from the 7 year olds to the 11 year olds, there was no noticeable drop in the proportion of irrationality from the 11 year olds to the 21 years olds. In other words, children by the age of 11 have fully developed their cognitive skills regarding basic orderings. Furthermore, they found that mathematical ability did not explain the ability to be rational proving that rationality was a characteristic developed through general experience and not certain mental abilities.

This study is important, for if we are to take other studies seriously, we must be somewhat satisfied that the subjects we are studying are behaving according to one of the most basic axioms of economic behavior. Moving on to the subject at hand, the most direct study of juvenile crime was conducted by the economist Steven Levitt. ${ }^{86}$ In his pathbreaking study, Professor Levitt examined the relationship between punishment and crime committed by juveniles for the period 1978-1993. In his study he found that, in fact, juveniles are deterred by punishment, and that juvenile deterrence was similar to adult deterrence by punishment. He started his study by observing that during this time period, juvenile crime rates, especially violent crime, had been rising at a rate faster than adult crime rates. He also noted that juvenile punishment had fallen in severity by half during this time period, while the severity of adult punishment had risen by over 60 per cent. Using data from across the states, Levitt was able to study the relationship between the variation in punishment across states and the rate of juvenile crime in those states.

\footnotetext{
${ }^{86}$ Levitt, supra note 15.
} 
Levitt looked at the impact of the incarceration rate on the number of crimes committed by juveniles. He found that there was a statistically significant negative relationship between the two variables. He estimated that for each extra delinquent incarcerated, there was a reduction of between 0.49 and 0.66 violent crimes. For property crimes, the reduction was between three and four crimes. The adult custody rate was also negatively associated with the juvenile violent crime rate (although it was positively associated with property crimes). This suggests that since adults were being punished quite harshly for violent crime, a juvenile realized a lower return from engaging in violent crimes, perhaps since juveniles who commit violent crimes tend to continue committing such crimes in their adult life. If adults are being harshly punished, this lowers the return from committing such crimes today. Property crimes, on the other hand, do not seem to have this continuity effect; and hence if adults are being incarcerated longer for property crimes, there are more property crime opportunities for juveniles.

Levitt then examined the impact of punishment on adult crime. He found that adding one more adult prisoner to the adult prisoner population lowered adult violent crime by between 0.12 and 0.69 , and by between 1 and 3 property crimes. Recall that juveniles reduced their violent crimes by between 0.49 and 0.66 and property crimes by between three and four in response to one extra juvenile incarcerated. Punishment, therefore, has a greater (if not equal) deterrence impact on juveniles than adults. This suggests that juveniles have a more elastic demand for crime than adults, and also calls into question the underlying assumptions of the Roper decision.

Professor Levitt also investigated another aspect of juvenile crime. He looked at the impact of the relative harshness of adult punishment to juvenile punishment on crimes committed by juveniles who have reached the age of majority. Given that for some states the age of majority is 18 while for others it is 17 , this statistical investigation provides us with a look at 
whether juveniles are rational and able to conduct cost-benefit analysis regardless of whether they are 17 or 18 years of age. In fact, he found that as juveniles transitioned into adulthood, no matter what the age of majority, crimes committed by the new adults were negatively influenced by the relative harshness of adult punishment. In states where adults were punished far more severely than juveniles, when a juvenile reached the age of majority violent and property crimes dropped. In states where a juvenile reaches the age of majority at 17 , the new adults committed less violent and property crimes than their 17 year old counterparts in those states where the age of majority was 18.

These results belie the claim that juveniles are undeterrable and hence less culpable. It also points to the futility of drawing an arbitrary line of 18 years for when an individual can be executed. If anything, they react just as rationally to the incentives of punishment as adults do. What is lacking is not the rationality, but punishment as severe as that meted out to adults, for most juveniles are punished quite lightly compared to their adult counterparts. Levitt was able to conclude that what explains the relative increase in juvenile crime is the decline in severity of punishment. He estimated that 60 per cent of the increase in juvenile crime could be attributed to the drop in juvenile punishment. The United States Supreme Court's decision in Roper will now be a further hindrance to states in their efforts to combat juvenile crime.

Other studies seem to confirm Levitt's results. For example, Professors Naci Mocan and Daniel Rees looked at a sample of 16,478 high school children surveyed in $1995 .^{87}$ Their study had the advantage of looking at individual behavior as opposed to aggregate crime rates as in Levitt's article. Their dataset contained individual data on youth aged 13-17 from a wide cross section of society. The juveniles were asked a set of questions as to whether they had committed

\footnotetext{
${ }^{87}$ H. Naci Mocan \& Daniel Rees, Economic Conditions, Deterrence and Juvenile Crime: Evidence from Micro Data, forthcoming in AM L. ECON. REV available at http://papers.ssrn.com/sol3/papers.cfm?abstract_id=193632.
} 
certain crimes and how frequently. ${ }^{88}$ The authors then matched this data with data on the crime rate, arrest rates for violent and property crimes (for both adults and youth) in the county of residence of the juveniles. ${ }^{89}$ The crime categories included selling marijuana, assault, robbery, and burglary. The authors found that the arrest rates negatively impacted the probability of juveniles selling drugs. Specifically, they found that one additional arrest for a violent crime reduced by 4 per cent the probability of selling drugs by male juveniles. Male juveniles reduced their probability of assault by 6 per cent for each arrest, although robbery and burglary by males were not responsive to arrest rates. On the other hand, female juveniles lowered their theft and drug sales in response to violent crime arrests. ${ }^{90}$ Given that the death penalty is a tool aimed primarily at the most violent of crimes, namely murder, the fact that male juveniles committing assaults or selling drugs were responsive to arrest rates suggests that a fortiori they would be very responsive to the presence of the death penalty as a punishment.

What these studies show is that juveniles do respond to arrest rates and punishment, especially for violent crimes, and that they respond (as the Levitt study showed) by at least as much to punishment as adults do. This suggests that if we can establish that the death penalty is a deterrent against murders for all members of society, we can extrapolate from this that juveniles will be equally deterred from committing homicides.

\footnotetext{
${ }^{88}$ Self-reported data always has its limitations, but the authors were able to verify that the data conformed to other datasets that did not rely on surveys.

${ }^{89}$ The authors also looked at other variables as determinants of juvenile crime such as religious beliefs, parental education, and unemployment rates.

${ }^{90}$ Another study using experimental data also found that juveniles responded to penalties. Michael Visser, Bill Harbaugh, \& H. Naci Mocan, An Experimental Test of Criminal Behavior among Juveniles and Young Adults: GARP among Thieves, available at http://darkwing.uoregon.edu/ mvisser1/GARP_among_thieves.pdf. Another study looked at 317 Chicago males whose average age was 16 and who were sentenced to prison for the first time. The study concluded that prison served as a deterrent as the group's subsequent arrest rate fell by two-thirds. Charles Murray \& Louis CoX JR., Beyond Probation: JuVEnile Corrections AND the ChroniC DELINQUENT (1979).
} 
Studies on the deterrent effect of the death penalty have been conducted for many years. The first major study was conducted by Thorsten Sellin, a sociologist, who used crude empirical methods to arrive at the conclusion that capital punishment did not deter against homicide. ${ }^{91}$ This idea seems to be acceptable among many, ${ }^{92}$ despite the number of studies that have now shown conclusively that the death penalty does deter against homicides. The first such study was conducted by the economist Isaac Ehrlich who looked at the homicide rate and its relationship to a variety of variables in the United States during the time period 1933-1969. ${ }^{93}$ In his study, he found that three variables negatively affected homicide rates in a statistically significant manner. They were the probability of arrest, probability of conviction, and the probability of execution in that order of importance. He concluded that each additional execution per year resulted in seven or eight fewer homicides each year. There were several methodological critiques of Ehrlich's study, ${ }^{94}$ and in response to these, Ehrlich re-did his study using cross-sectional data for the various states during one or two time periods only and again found support for his conclusion that the death penalty was a deterrent. ${ }^{95}$ Following this set of work, a flurry of articles followed

\footnotetext{
91 ThOMAs SEllin, CAPITAl PUniSHMnet (1967). For a critique of his methodology, see RoBERT COOTER \& THOMAS ULEN, supra note 52 502-3.

${ }^{92}$ See e.g. Helmut Kury, Theodore N. Ferdinand, \& Joachim Obergfell-Fuchs, Does Severe Punishment Mean Less Criminality? 13 InT. CRIM. JuST. REV. 110 (2003); James M. Galliher \& John F. Galliher, A “Commonsense” Theory of Deterrence and the "Ideology” of Science: The New York State Death Penalty Debate, 92 J. CRIM. L. CRIMINology 307 (2002); Allan D. Johsnon, The Illusory Death Penalty: Why America's Death penalty Porcess fails to Support the Economics Theories of Criminal Sanctions and Deterrence, 52 HASTINGS L.J. 1101 (2001); Michael Radelet \& Ronald L. Akers, Deterrence and the Death Penalty: The Views of the Experts, 87 J. CRIM. L. \& CRIMINology 1 (1996); Jonathan S. Abernethy, The Methodology of Death: Reexamining the Deterrence Rationale, 27 Colum. HuM. RTS. L. REV. 379 (1996).

${ }^{93}$ Isaac Ehrlich, The Deterrence Effect of Capital Punishment: A Question of Life and Death, 65 AM. ECON. REV. 397 (1975).

${ }^{94}$ See e.g. Peter Passel \& John B. Taylor, The Deterrent Effect of Capital Punishment: Another View, 57 AM. EcON. REV. 445 (1977) (finding that when the period of 1962-1967 was excluded due to virtual absence of the death penalty in those years, the deterrence effect disappears).

${ }^{95}$ Isaac Ehrlich, Capital Punishment and Deterrence: Some Further Thoughts and Additional Evidence, 85 J. PoL. ECON., 85741 (1977). See also Isaac Ehrlich, Deterrence, Evidence and Inference, 85 YALE L. J. 209 (1975); The Deterrent Effect of Capital Punishment: Reply, 67 AM. ECON. REV. 452 (1977); The Optimum Enforcement of Laws and the Concept of Justice: A Positive Analysis, 2 InT. REV. LAW \& ECON. 3 (1982); supra note 52; Crime, Punishment and the Market for Offences, 10 J. ECON. PERSPECTIVES 43 (1996); Isaac Ehrlich \& J. Gibbons On the Measurement of the Deterrent Effect of Capital Punishment and the Theory of Deterrence, 6 J. LEG. STUD. 35
} 
investigating the deterrence effect of capital punishment; some found a deterrence effect, ${ }^{96}$ while others did not. ${ }^{97}$ The problem with all these studies, as economist Joanna Shepherd has pointed out, is that the data is either aggregated nationally which prevents the researcher from looking at cross-state variations or the data is a cross-section of states during one time period which prevents the researcher from looking at trends over time. ${ }^{98}$

To overcome these methodological problems, a new series of articles have emerged where the researchers used pooled data: data that varies over time and that also comes from a

(1977); Isaac Ehrlich \& Z. Liu, Sensitivity Analysis of the Deterrence Hypothesis: Let's Keep the Econ in Econometrics, 42 J. LAW \& ECON. 455 (1996).

${ }^{96}$ James A. Yunker, A New Statistical Analysis of Capital Punishment Incorporating U.S. Postmoratorium Data, 82 Soc. SCI. Q. 297 (2001) (finding some support for the deterrent effect of the death penalty); James Hennessy et. al, Crime and Punishment: Infrequently Imposed Sanctions May Reinforce Criminal Behavior, 29 JouRnAL OF OFFENDER REHABILITATION 65 (1999) (finding some support for deterrence effect); Samuel Cameron, A Review of the Econometric Evidence on the Effects of Capital Punishment, 23 J. SOCIO-ECON. 197 (1994) (explaining why many studies show no deterrence effect and rebutting many of the claims that the data show no impact of the death penalty); Steven Stack, Execution Publicity and Homicide in South Carolina: A Research Note, 31 THE Soc. Q. 599 (1990) (finding a drop in homicides after a publicized execution); George A. Chressanthis, Capital Punishment and the Deterrent Effect Revisited: Recent Time Series Econometric Evidence, 18 J. BEHAVIORAL ECON. 81 (1989) (finding support for the deterrent effect during the 1965-1985 time period); Steven Stack, Publicized Executions and Homicide, 1950-1980, 52 AM. Soc. REV. 532 (1987) (finding a drop of 30 homicides after each publicized execution); James A. Yunker, Testing the Deterrent Effect of Capital Punishment: A Reduced Form Approach, 19 CRIMINOLOGY 626 (1982) (suggesting that the capital punishment moratorium may have increased homicide rates); David P. Phillips, The Deterrent Effect of Capital Punishment: New Evidence on an Old Controversy, 86 AM. J. SoC. 139 (1980) (finding a drop in the homicide rate by $35.7 \%$ after a publicized execution); James A. Yunker, Is the Death penalty a Deterrent to Homicide? Some Time Series Evidence, 5 J. BEHAVIORAL ECON. 45 (1976) (finding some evidence of a deterrent effect).

${ }^{97}$ Richard Berk, New Claims about Executions and General Deterrence: Déjà vu all over Again?, forthcoming J. EMPIRICAL LEG. STUD. available at http://preprints.stat.ucla.edu/396/JELS.pap.pdf; Jon Sorensen et. al, Capital Punishment and Deterrence: Examining the Effect of Executions on Murder in Texas, 45 CRIME AND DELINQUENCY 481 (1999) (no support for deterrence effect of death penalty in Texas); William C. Bailey, Deterrence,

Brutalization, and the Death Penalty: Another Examination of Oklahoma's Return to Capital Punishment Bailey, 36 CRIMINOLOGY 711 (1998) (finding weak or no support for deterrence effect); John K. Cochran, Mitchell B. Chamlin,\& Mark Seth, Deterrence or Brutalization? An Impact Assessment of Oklahoma's Return to Capital Punishment, 32 CRIMINOLOGY 107 (1994) (no evidence of deterrence effect); Jeffrey Grogger, The Deterrent Effect of Capital Punishmnet: An Analysis of Daily Homicide Counts, 85 J. AM. STAT. ASS'N 295 (1990) (finding no evidence of drop in homicides following an execution); William Bailey \& Ruth D. Peterson, Murder and Capital Punishment: A Monthly Time-Series Analysis of Execution Publicity, 54 AM. SoC. REv. 722 (1989) (taking issue with the Stack study and finding that there is no or very little effect of the death penalty on homicides); Peter Passel \& John B. Taylor, The Deterrent Effect of Capital Punishment: Another View, 67 AM. ECON. REV. 445 (1977) (no effect); Stephen A. Hoenack \& William C. Weiler, A Structural Model of Murder Behavior and the Criminal Justice System, 70 AM. ECON. REV. 327 (1980) (no effect).

${ }^{98}$ Joanna M. Shepherd, Deterrence versus Brutalization: Capital Punishment's Differing Impacts among States, forthcoming in MICH. L. REV. available at http://law.bepress.com/cgi/viewcontent.cgi?article=1000\&context=emorylwps. Her study contains a comprehensive citation to many of the studies. 
cross-section of states. These articles seem to all support the proposition that the death penalty deters. Paul Zimmerman looked at state-level data from 1978 onwards and found that there was a deterrence effect, where each execution reduced an average of 14 homicides. ${ }^{99}$ Naci Mocan and Kaj Gittings also found a deterrence effect when they looked at state-level data from 19771997, and they estimated that each execution deterred five homicides. ${ }^{100}$ Additionally, they found that commuting death sentences increased the murder rate. Joanna Shepherd found that it did not matter whether the murder was a crime of passion or a murder by an intimate of another (crimes usually claimed to be undeterrable), they also were reduced in the presence of executions. ${ }^{101}$ She estimated that each execution lowered three murders, while the passing of a death sentence reduced it by 4.5 murders. She also found that as the waiting period on death row was reduced, murders were deterred: one murder for every 2.75 years reduced before execution. This last observation is consistent with the prediction of economic theory that the further away the execution, the more criminals will discount the cost of committing a crime and hence commit more crimes. Another study found that 91 per cent of states that suspended the death penalty following the United States Supreme Court's moratorium on execution during the 1972-1976 period faced an increase in their murder rates, while 70 per cent of the states that re-introduced the death penalty after the moratorium saw a drop in the murder rate. ${ }^{102}$ Using county-level data for 3,054 counties during the 1977-1996 period, three researchers found that each execution

\footnotetext{
${ }^{99}$ Paul R. Zimmerman, State Executions, Deterrence, and the Incidence of Murder, 7 J. Appl. Econ. 163 (2004); See also Paul R. Zimmerman, Estimates of the Deterrent Effect of Alternative Execution Methids in the United States: 1978-2000, forthcoming AM. J. ECON. \& SoC. available at http://papers.ssrn.com/sol3/papers.cfm?abstract_id=355783.

${ }^{100}$ H. Naci Mocan \& Kaj Gittings, Getting off Death Row: Commuted Sentences and the Deterrent Effect of Capital Punishment, 46 J. L. ECON. 453 (2003).

${ }^{101}$ Joanna M. Shepherd, Murders of Passion, Execution Delays, and the Deterrence of Capital Punishment, $33 \mathrm{~J}$. LEG. STUD. 283 (2004).

${ }^{102}$ Hashem Dezhbakhsh \& Joanna Shepherd, The Deterrent Effect of Capital Punishment: Evidence from a Judicial Experiment, working paper available at $\mathrm{http} / / /$ papers.ssrn.com/sol3/papers.cfm?abstract_id=432621.
} 
reduced murders by 18 , thereby providing the strongest proof of the deterrence effect given the

highly disaggregated nature of the data used. ${ }^{103}$

These and other studies concerning the deterrence effect of capital punishment ${ }^{104}$ and punishment in general ${ }^{105}$ all point to the inescapable conclusion that the death penalty does deter, and have led some prominent legal scholars to claim that the death penalty is "morally

${ }^{103}$ Hashem Dezhbakhsh, Paul Rubin, \& Joanna M. Shepherd, Does Capital Punishment Have a Deterrent Effect? New Evidence from Postmoratorium Panel Data, 5 AM. L. ECON. ReV. 344 (2003).

${ }^{104}$ See e.g. Dale O. Cloninger \& Roberto Marchesini, Execution and Deterrence: A Quasi-Controlled Group Experiment, 5 APPL. ECON. 569 (2001) (finidng that the Texas unofficial moratorium on executions during 1996 caused an increase in homicides which fell after the moratorium was lifted); Ehrlich \& Zhiqiang, supra note 95; Liu Zhiqiang, Capital punishment and the Deterrence Hypothesis: Some New Insights and Empirical Evidence, 30 East. Econ J. 237 (2004) (finding strong support for the deterrent effect of the death penalty).

${ }^{105}$ There are numerous studies that have studied the impact of punishment on crime. Isaac Ehrlich (who investigated the death penalty as discussed in note 95 supra) looked at robberies in the United States in 1940, 1950, \& 1960. Isaac Ehrlich, Particpation in Illegitimate Activities: A Theoretical and Empirical Investigations, $81 \mathrm{~J}$. POL. ECON. 521 (1973). He found that the higher the probability of conviction, the lower the crime rate. He also found no deterrent effect for the severity of punishment, as measured by the length of the prison sentence for robbery, in the years 1940 and 1960, but he did find a deterrence effect for the year 1950. Subsequent studies found support for the proposition that punishment does deter. Se e.g. Lawrence Katz, Steven D. Levitt, \& Ellen Shustorovich, Prison Conditions, Capital Punishment, and Deterrence, 5 AM. L. ECON. REv. 318 (2003) (finding that death rates among inmates, which can be thought of as an indicator of prison conditions, lowers both property and violent crimes); Joanna Shepherd, Fear of the First Strike: The Full Deterrent Effect of California's Two-and Three-Strikes Legislation, 31 J. LEG. STUD. 159 (2002); Jeff Desimone, The Effects of Cocains Prices on Crime, 39 ECON. INQUIRY 627 (2001) (finding that arrest rates have a negative impact on most crimes); Hope Corman \& H. Naci Mocan, A Time Series Analysis of Crime, Deterrence, and Drug Abuse in New York City, 90 AM. ECON. REv. 584 (2000) (finding strong support for the deterrence effect - specifically crimes dropped in response to an increase in arrest rates); Steven D. Levitt, Why do Increased Arrest Rates Appear to Reduce Crime: Deterrence, Incapacitations, or Measurement Error, 36 ECON. INQUIRY 353 (1998) (finding that increased arrests also deter against additional criminal committing crime and do not simply incapacitate existing criminals); Steven D. Levitt, The Effect of Prison Population Size on Crime Rates: Evidence from Prison Overcrowding Litigation, Q. J. ECON. 319 (1996) (finding that one extra incarceration lowers the number of crimes committed each year by 15); Samuel Myers, Estimating the Economic Model of Crime: Employment versus Punishment Effects, 98 Q. J. EcON. 157 (1983) (finding a deterrent effect for severity of punishment); Ann Witte, Estimating the Economic Model of Crime with Individual Data, 94 Q. J. ECON. 57 (1980) (finding that severity of punishment had higher deterrent effect for violent criminals that those committing property crimes); Kenneth Wolpin, An Economic Analysis of Crime and Punishment in England and Wales 1894-1967, 86 J. POL. ECON. 815 (1978) (finding that punishment deterred crime in England and Wales); DETERRENCE AND INCAPACITATION: ESTIMATING THE EFFECTS OF CRIMINAL SANCTIONS ON CRIME RATES (Alfred Blumstein, Jacqueline Cohen, \& Daniel Nagin eds., 1978); Alfred Blumenstein \& Daniel Nagin, The Deterrent Effect of Legal Sanctions on Draft Evasion, 28 STAN L. REV. 241 (1977) (finding that higher penalties reduced draft evasion). For a comprehensive survey of the literature, see Eide, supra note 52 at 359 ("The great majority of correlation studies and cross-section regression analyses show a clear negative association between punishment variables and the crime rate. Almost without exception the coefficients of the punishment variables ... are negative, and in most of the cases significantly so."). An earlier survey by Eide of the literature can be found in ERLING EIDE, ECONOMICS OF CRIME: DETERRENCE AND THE RATIONAL OFFENDER (1994). An older but classic collection of theoretic and empirical studies on criminal behavior is ECONOMIC MODELS OF CRIMINAL BEHAVIOR (J.M. Heineke ed., 1978). 
required."106 What it should also point to, for the purposes of this paper is that the death penalty will also deter juveniles.

\section{The Indirect Evidence}

The premise of the majority in Roper and the supporting amicus briefs was that juveniles could not be deterred since they lack rational thought or if they do possess rational thought (as the AMA conceded) their rationality and ability to calculate is clouded by certain myopic and euphoric impulses. Despite the fact that those claims do not necessitate the abolition of the death penalty for juveniles and if anything, they call for the opposite conclusion, as I argued earlier, the very premise requires some empirical verification. In this sub-section, I shall present some of the empirical evidence regarding the rationality of children, juveniles, and other so-called irrational members of society.

One of the best economic studies of youth behavior is the book edited by professor Jonathan Gruber titled Risky Behavior among Youths : An Economic Analysis, where a series of articles by eminent economists examined various aspects of risky youth behavior. ${ }^{107}$ What the studies found was that even youth respond to economic incentives when engaging in risky behavior. For example, in a study using data for the period 1991-1997 teen smoking was found to be very responsive to cigarette prices. ${ }^{108}$ This result is one of many in a series of studies that have shown that even addiction can be economically rational.

For long, addicts were characterized as undeterrable. Whether the addiction was to alcohol, tobacco, or drugs, it was assumed that those addicted to these substances could not lower their consumption. An implication of this assumption would be that if the price of the

\footnotetext{
${ }^{106}$ Cass Sunstein \& Adrian Vermule, Is Capital Punishment Morally Required? The Relevance of Life-Life Tradeoffs, available at http://papers.ssrn.com/sol3/papers.cfm?abstract_id=691447.

${ }^{107}$ RISKY BEHAVIOR AMONG YOUTHS : AN ECONOMIC ANALYSIS (Jonathan Gruber ed., 2001).

${ }^{108}$ Jonathan Gruber \& Jonathan Zinman, Youth Smoking in the United States: Evidence and Implications in RISKY BEHAVIOR AMONG YOUTHS : AN ECONOMIC ANALYSIS 69 (Jonathan Gruber ed., 2001).
} 
addictive substance were to increase, the consumption by the addict would not change. This is contrary to normal consumer behavior where an increase in price would lead to a reduction in quantity consumed. Economic studies, however, have shown the contrary: in fact, even addicts are rational and they will alter their behavior in response to price changes. ${ }^{109}$

Even the mentally ill have been found to act rationally. A study found that those with a history of mental illness were more likely to consume alcohol, cigarettes, and cocaine than individuals with no mental illness, but they were also found to be price-responsive. ${ }^{110}$ Even 44 female psychotics (primarily schizophrenics) in a mental institution were found to act rationally. When they were rewarded for the performance of certain tasks they each performed about an hours worth of tasks (such as laundry and cooking), but when they were rewarded regardless of task performance the patients eventually did not perform at all. ${ }^{111}$

Returning to smoking juveniles, a study using experimental methodology that looked at juvenile smoking behavior also confirmed that price will negatively impact their consumption. ${ }^{112}$

\footnotetext{
${ }^{109}$ The key article to posit a theory of rational addiction was by Gary S. Becker \& Kevin M. Murphy, A Theory of Rational Addiction, 96 J. POL. ECON. 675 (1988). Empirical confirmation of their theory can be found in Gary S. Becker \& Kevin M. Murphy, An Empirical Analysis of Cigarette Addiction, 84 AM. Econ. Rev. 396 (1994). See also Jenny Williams, Habit Formation and College Students' Demand for Alcohol, 14 HeALTH ECon. 119 (2005); Ziggy MacDonald, What Price Drug Use? The Contribution of Economics to an Evidence-Based Drugs Policy, $18 \mathrm{~J}$. ECON. SURVEYS 113 (2004); Mikael Bask \& Maria Melkersson, Rationally Addicted to Drinking and Smoking, 36 APPL. ECON. 373 (2004); Jonathan Gruber \& Botond Koszegi, Is Addiction 'Rational'? Theory and Evidence, 116 Q. J. ECON. 1261 (2001); Frank J. Chaloupka \& Kenneth Warner, The Economics of Smoking in HANDBOOK OF HEALTH ECONOMICS 1539 (Anthony Culyer \& Joseph Newhouse eds., 2000); John F.P. Bridges, Can Economics Add to the Illicit Drug Debate, 18 Drug \& Alcohol Rev. 251 (1999); Michael Grossman, Frank J. Chaloupka, \& Richard Anderson, A Survey of Economic Models of Addictive Behavior, 28 J. DRUG IsSUES 631 (1998); Samuel Cameron, Are Greek Smokers Rational Addicts, 4 APPL. ECON. LeTTERS 401 (1997); Jan C. van Ours, The Price Elasticity of Hard Drugs: The Case of Opium in the Dutch East Indies, 1923-1938103 J. POL. ECON. 261 (1995); Gary S. Becker, Habits, Addictions and Traditions, 45 KYKLOS 327 (1992);Frank J. Chaloupka, Rational Addictive Behavior and Cigarette Smoking, 99 J. POL. ECON. 722 (1991).

${ }^{110}$ Henry Saffer \& Dhaval Dave, Mental Illness and the Demand for Alcohol, Cocaine, and Cigarettes, 43 ECON. INQUIRY 229 (2005).

${ }^{111}$ T. Ayllon \& N.H. Azrin, The Measurement and Reinforcemnet of Behavior of Psychotics, 8 J. EXPERIMENTAL ANALYSIS OF BEHAVIOR 357 (1965). In another study, animals were also found to act rationally. JOHN H. KAGEL, RAYMOND C. BATTALIO, \& LEONARD GREEN, ECONOMIC CHOICE THEORY : AN EXPERIMENTAL ANALYSIS OF ANIMAL BEHAVIOR (1995).

${ }^{112}$ Hana Ross et. al, New Evidence on Youth Smoking Behavior Based on Experimental Price Increases, 23 CONTEMPORARY ECON. POLICY 1074 (2005).
} 
Marijuana usage by juveniles was also found to be price sensitive. ${ }^{113}$ Another study found that cocaine addiction by high school seniors also fit the rational addiction model, as the demand for cocaine was price sensitive, ${ }^{114}$ and alcohol consumption by the same group was also found to be price sensitive. ${ }^{115}$

Even non-consumption risky behavior was found to be responsive to incentives. Teenage pregnancies, for example, fell as welfare benefits fell (thereby reducing the payoff for an out-ofwedlock child), but even non-price variables affected risky teenage behavior, as teenage pregnancies declined as the incidence of AIDS grew. ${ }^{116}$

Another study found that juveniles did respond to legal variables as minimum legal drinking ages reduced underage teenage drinking. ${ }^{117}$ Similarly minimum smoking ages reduced underage teenage smoking, ${ }^{118}$ and mandatory seat belt laws reduced vehicle fatalities among youth. ${ }^{119}$ In contrast, those activities that did not have an age specific legal restriction, such as smoking marijuana, did not have an age specific pattern for youth. ${ }^{120}$

All in all, the econometric evidence points to the proposition that even youth are rational who respond to incentives in a consistent and measurable manner, thereby suggesting that juveniles can be deterred.

\footnotetext{
${ }^{113}$ Rosalie L. Pacula et. al, Marijuana and Youth, in RISKY BEHAVIOR AMONG YOUTHS : AN ECONOMIC ANALYSIS 271 (Jonathan Gruber ed., 2001).

${ }^{114}$ Michael Grossman \& Frank J. Chaloupka, The Demand for Cocaine by Young Adults: A Rational Addiction Approach, 17 J. HEALTH ECON. 427 (1998).

${ }^{115}$ Michael Grossman, Frank J. Chaloupka, \& Ismail Sirtalan, An Empirical Analysis of Alcohol Addiction: Results from the Monitoring the Future Panels, 36 ECON. INQUIRY 39 (1998).

${ }^{116}$ Phillip B. Levine, The Sexual Activity and Birth-Control Use of American Teenagers, in RISKY BEHAVIOR AMONG YOUTHS: AN ECONOMIC ANALYSIS 167 (Jonathan Gruber ed., 2001).

${ }^{117}$ Phillip J. Cook \& Michael J. Moore, Environment and Persistence in Youthful Drinking Patterns, in RISKY BEHAVIOR AMONG YouTHS: AN ECONOMIC ANALYSIS 375 (Jonathan Gruber ed., 2001).

${ }^{118}$ Gruber \& Zinman supra note 108.

119 Thomas S. Dee \& William N. Evans, Teens and Traffic Safety, in RISKY BEHAVIOR AMONG YOUTHS : AN ECONOMIC ANALYSIS 121 (Jonathan Gruber ed., 2001).

${ }^{120}$ Rosalie L. Pacula et. al, supra note 113.
} 


\section{What does this mean for the Death Penalty and other Forms of Punishment?}

Given that capital punishment was the default rule in America since its founding, and given that there is a large body of work that suggests the obvious idea that capital punishment will deter, it seems curious that the Supreme Court would have removed from the states a longstanding tool in their arsenal against juvenile crime. The burden of proof should rest on the shoulders of those who seek to abolish the ability of states to fashion their own policies for controlling crime within their boundaries. Had economists filed an amicus brief in the Roper case, one wonders if the result might have been different.

The policy implications of this paper are clear. States should be allowed to set penalties as high as they feel necessary to deter juveniles from crime. Combating crime means also means that states could also invest in detection and conviction. Some have suggested that since the juvenile penalties are so low as compared to adults, many police officers do not invest in the resources needed to combat juvenile crime. ${ }^{121}$ This is unfortunate. If low penalties mean less policing, then this amplifies the message that it is acceptable for juveniles to commit crimes. If indeed juveniles are risk-takers who underestimate their chances of being caught and who place a high emphasis on present gratification, then the states need to treat juveniles with harsher modalities of punishment than adults.

A frequent criticism of the justice system today is the delay between the time of the crime and the time of punishment. Even a risk-averse individual with normal discount rates may decide to commit a crime if the delay in penalty is large enough. If juveniles are even hastier than adults, a punishment mechanism that allows for immediate punishment must be found. There are preventative measures that may help. Night curfews for youth are one example. If youth are kept off the streets after a certain time, and if they can be punished for violating

\footnotetext{
${ }^{121}$ Levitt, supra note 15 , at 1175, n.17.
} 
curfew, then curfews will serve two purposes. The first is that they will lower youth exposure to the negative peer pressure that many youth face and that lures them to a life of crime. The second is that by punishing curfew-breakers, it sends a message that society is serious about law and order. It can also teach them that breaking the law is unacceptable. My proposal would also add that the penalty for violating the curfew should be severe. The severity will send a message of our disapproval of young men and women roaming around in search of the illicit. It will also serve as a deterrent. For if violating a simple curfew will yield a harsh reaction, what could an assault or robbery possibly hold? - or so a youth may ask himself.

The types of punishments for youth must also be re-considered. If indeed they respond to present and immediate stimuli more than promised events in the future, then the immediacy of punishment is a must. One proposal is to allow state corporal punishment. ${ }^{122}$ Youth who are arrested under highly suspicious circumstances for violent crimes must have pain inflicted upon them. This will somehow make them appreciate their actions in the recesses of their amygdala far from its more thoughtful counterpart the frontal cortex. After all, the AMA tells us, they cannot be reasoned with as adults. Though their guilt may not be certain at the time of arrest, but were they acquitted later on, the state could compensate them for the wrongful punishment. But the message would be clear: we will not tolerate the heinous crimes that they commit. Sending such a message will shape juveniles' preferences to recognize that committing heinous crimes is morally and socially unacceptable, something the skeptics of the deterrent effect of punishment for juveniles have argued is one of the few factors that reduces juvenile crime. ${ }^{123}$

\footnotetext{
${ }^{122}$ Such punishments were once common for adults and youth alike in America, England, and Europe. MICHEL FouCAult, DisCIPLINE \& PUNISH: THE BIRTH OF THE PRISON (Alan Sheridan trans., 1995); LAWRENCE M. FrIEDMAN, CRIME AND PUNISHMENT IN AMERICAN History (1993); ChristopHER HibBERT, THE ENGLISH: A SOCIAL HISTORY 1066-1945 239 (1987).

${ }^{123}$ Schneider \& Ervin, supra note 82. For the idea that laws can shape individual's preferences, see Kenneth G. Dau-Schmidt, An Economics Analysis of the Criminal Law as a Preference-Shaping Policy, 1990 DUKE L.J. 1 (1990).
} 
Professor Kontorovich has called this idea a liability rule of constitutional rights. ${ }^{124} \mathrm{He}$ argued that under certain urgent circumstances, the state should be allowed to engage in protective measures that may violate certain individual's rights. Rather than a property rule that enjoins the state from carrying out its protective measures, the rule should be a liability rule whereby some compensation is paid out. Society is protected and those aggrieved are compensated. I would argue for a similar application here. Mr. Simmons was arrested and he confessed after his partners in crime identified him. His trial, conviction, and sentence was many months later. In the intervening time period, had he been subject to hard labor, caning, or some other harsh punishment, the message would be loud and clear. In the odd event that he was acquitted, a measure of compensation could be paid out. But it would have served its purpose, namely the transmission of the message to other juveniles who were contemplating committing a heinous crime. While the state could lose some money from compensation, society would be better off due to the reduced crime rate.

The idea of escalating penalties is not new or novel. Professor David Dana has argued that, especially for regulatory offenses, we should punish first time offenders more severely than when the same offender subsequently re-offends. ${ }^{125}$ The probability of detection for a first-time offender is low, but the probability of detection for repeat offenders increases. Hence, economic theory dictates that the first offense should be punished most severely, since that is what is needed to deter, while repeat offenders can easily be deterred by lower punishments.

Similarly, Gary Becker in his analysis of the economics of illegal goods (such as drugs) concludes that it may be socially optimal to punish "smaller, younger, and weaker suppliers"

\footnotetext{
${ }^{124}$ Eugene Kontorovich, The Constitution in Two Dimensions: A Transaction Cost Analysis of Constitutional Remedies, forthcoming 91 VA. L. REV. available at http://papers.ssrn.com/sol3/papers.cfm?abstract_id=599963; Liability Rules for Constitutional Rights: The Case of Mass Detentions, 56 STANFORD LAW REVIEW 755 (2004). ${ }^{125}$ David A. Dana, Rethinking the Puzzle of Escalating Penalties for Repeat Offenders, 110 YALE L.J. 733 (2001).
} 
more heavily than bigger and more efficient producers. While punishing drug couriers, who are usually poor and themselves addicted to drugs, more severely than the organized crime leader may indicate the presence of corruption; Becker argues that this may also be a sign of socially optimal levels of enforcement. ${ }^{126}$ This is because targeting the efficient producers does not deter much, while targeting the less efficient producers has a greater impact on the overall supply of drugs. Juveniles sense that the odds of detection are lower than what they really are, and hence to deter them higher penalties are needed. This was argued above and is in line with Dana's argument. The novelty of Becker's analysis also aids in thinking about juvenile punishment. If juveniles are indeed hapless, helpless, impressionable, and unable to calculate the costs and benefits of their crimes, then they are similar to Becker's small, young, and weak drug suppliers. They, therefore, deserve to be punished more severely than their adult counterparts.

Lest the reader forget, my recommendations are premised on juveniles behaving as characterized by the majority, the AMA, and the APA in Roper. The empirical evidence, though, seemed to suggest that juveniles may behave as rationally as adults. If that is in fact true, then my drastic solutions are not needed. All that is needed is the flexibility for the states to tailor their policies as they see fit.

\section{Culpability and our Attitude towards Juveniles}

So far, I have dealt with the question of deterrence. The question of culpability was premised on the same assumptions that the majority in Roper used to justify the lack of any deterrence for juveniles. The empirical evidence, however, has shown that juveniles can be deterred. This puts into doubt the very assumptions that the majority rested their case for

\footnotetext{
${ }^{126}$ Gary S. Becker, Kevin M. Murphy, Michael Grossman, The Economic Theory of Illegal Goods: The Case of Drugs 24, NBER Working paper 10976 available at http://home.uchicago.edu/ gbecker/illegalgoods_Becker_Grossman_Murphy.pdf.
} 
diminished culpability for juveniles. If the factors that were supposed to diminish culpability also were supposed to diminish deterrability, but deterrence has been demonstrated empirically, then the existence of those factors must be questioned as well as the diminished culpability conclusion.

Historically, in criminal matters juveniles were treated equally with adults in England, although by the 1300 s, notions of maturity began to take hold in criminal law. ${ }^{127}$ By the time of Blackstone, the law had broken juveniles into three categories. Under the age of seven, no child was presumed to have any mental capacity to tell right from wrong and hence could be guilty of no crime or executed. ${ }^{128}$ Above the age of fourteen, which was deemed to be the age of puberty, all juveniles were presumed to distinguish between right and wrong and could be executed.

Between seven and ten, if the child was adjudged to have been able to distinguish between good and evil, they could be executed. It should be noted that the emphasis at common law was on whether the child could distinguish between right and wrong, and not whether they had an impulsive behavior caused by the lack of development. Children younger than seven were excused for the lack of discrimination between right and wrong, and so were the mentally ill (but not the mentally retarded). ${ }^{129}$ Culpability, therefore, always rested on the question of whether the individual could distinguish right from wrong. Effectiveness of punishment is therefore the proper tool for analyzing deterrence and not culpability. The Supreme Court conflated the two concepts and essentially mixed what was needed to prove one with what was needed for the

\footnotetext{
${ }^{127}$ Sanjeev Anand, Catalyst for Change: The History of Canadian Juvenile Justice Reform, 24 QUEEN's L.J. 515 (1999). Two classic articles that deal with the history of punishments for juveniles are A.W.G. Kean, The History of the Criminal Liability of Children, 53 L.Q. REv. 364 (1937); Victor L. Streib, Death Penalty for Children: The American Experience with Capital Punishment for Crimes Committed While under Age Eighteen, 36 OKLA. L. REV. 613 (1983).

1284 William BlaCKSTONE, COMMENTARIES *23-25.

${ }^{129}$ Atkins v. Virigina, 536 U.S. 304, 340 (2002) (Scalia, J. dissenting).
} 
other. The AMA, however, did answer the question of juvenile culpability when it stated that juveniles can distinguish between right and wrong. ${ }^{130}$

Assuming though that ability to engage in proper cost-benefit calculations is the correct yardstick for culpability, the Supreme Court has begun to travel down a dangerous path. The Court seems to have been dazzled by the array of medical evidence that the AMA and others presented in their amici briefs. The evidence claimed to show that the brains of juveniles are not as developed as adults. This medical evidence, the AMA claimed, was conclusive in showing that juveniles could not properly engage in calculating the costs and benefits of their crimes. The AMA argued that recent imaging studies of juveniles have shown that the "brain's frontal lobes are still structurally immature well into late adolescence.” Yet, as Ronald Bailey has pointed out, ${ }^{131}$ many adults such as drug addicts ${ }^{132}$ and violent adult psychopathic criminals also have underdeveloped frontal lobes. ${ }^{133}$ I noted earlier that pedophiles can also have highly impulsive behavior, and in fact, they too can be characterized by neurobiological traits. ${ }^{134}$ Two researchers claim that the Zodiac killer who terrorized the citizens of California actually suffered from "multiple personality disorder.", 135 Men who kill their spouses whom they believe are about to leave also have common neurobiological characteristics according to a researcher who claimed,

\footnotetext{
${ }^{130}$ See also Angelo v. People, 96 Ill. 209 (1880) (reversing the capital conviction of an eleven year old because the prosecution did not establish that the child could tell right from wrong) ("If this was true, and the evidence tended to prove it, the rule required evidence strong and clear beyond all doubt and contradiction, that he was capable of discerning between good and evil; and the legal presumption being that he was incapable of committing the crime, for want of such knowledge, it devolved on the People to make the strong and clear proof of capacity, before they could be entitled to a conviction.").

${ }^{131}$ Ronald Bailey, Bad Brains: How the Supreme Court's Teen Execution Decision Proves too Much, ReasonOnline (March 23, 2005) available at http://www.reason.com/rb/rb032305.shtml.

${ }^{132}$ Bailey supra note 131 (citing Dan I. Lubman, Murat Yücel \& Christos Pantelis, Addiction, a Condition of Compulsive Behaviour? Neuroimaging and Neuropsychological Evidence of Inhibitory Dysregulation, 99 ADDICTION 1491 (2004)).

${ }^{133}$ Id. (referring to Adrian Raine et. al, Reduced Prefrontal Gray Matter Volume and Reduced Autonomic Activity in Antisocial Personality Disorder, 57 ARCH. GEN. PSYCHIATRY 119 (2000)). See also Nora Volkow et. al, Brain Glucose Metabolism in Violent Patients: a Preliminary Study, 61 PSYCHIATRY RES. 243 (1995).

${ }^{134}$ Cohen \& Galynker, supra note 68.

${ }^{135}$ MiCHAEL D. KELlEHER \& DAVID VAN NuYS, THIS IS THE ZODIAC SPEAKING: INTO THE Mind OF A SERIAL KILLER (2002).
} 
"to establish that evidence has accumulated for a neurobiological link between abandonment and homicidal rage." "136 Interestingly, the author did concede that his study "should not be read as an attempt to remove the contextual features from intimate rage ...,"137 a point also conceded by another researcher who studies violent behavior. ${ }^{138}$ Even gambling, kleptomania, and compulsive buying have been blamed by researchers on the chemical composition in the brain. ${ }^{139}$ Rape has been observed in individuals suffering from brain injuries suggesting a medical aspect to "sexually intrusive behavior," 140 and racism, one study found, has roots in the amygdala, that region juveniles receive their impulsive anger from, but the study found that such racism could be overcome by the individual's attitude towards race. ${ }^{141}$ Surely no one would suggest that drug addicts, violent thugs, pedophiles, serial killers, jealous husbands who murder their wives, gamblers, thieves, compulsive shoppers, and racists should be less culpable for any crimes they may commit.

The idea of medical pre-dispositions can also be applied to gender differences. Simon Baron-Cohen argues that men and women have fundamentally different brains. ${ }^{142}$ Men are systematizers who try to identify the laws that govern a system, ${ }^{143}$ while females are empathizers who recognize that others have feelings and who respond by appropriate emotions. ${ }^{144}$ He cites this as evidence for why males may be more aggressive than females, namely the lack of empathy. His claims may be true and validated by other studies (one economic study did find

\footnotetext{
${ }^{136}$ Donald G. Dutton, The Neurobiology of Abandonment Homicide, 7 AGGRESSION \& VIOLENT BEHAV. 407 (2002).

${ }^{137}$ Id. at 418.

${ }^{138}$ Peter Fonagy, Towards a Developmental Understanding of Violence, 183 BRIT. J. PSYCHIATRY 190, 191 (2003) ("Such [biological] evidence does not preclude the relevance of social environment.").

${ }^{139}$ Jon E. Grant \& Marc N. Potenza, Impulse Control Disorders: Clinical Characteristics and Pharmacological Management, 16 ANNALs OF CLINICAL PSYCHIATRY 27 (2004).

${ }^{140}$ Scott C. Bezeau, Sexually Intrusive Behavior following Brain Injury: Approaches to Assessment and Rehabilitations, 18 BRAIN INJURY 299 (2004).

${ }^{141}$ Mary E. Wheeker \& Susan T. Fiske, Controlling Racal Prejudice: Social-Cognitive Goals Affect Amygdala and Sterotype Activation, 16 PSYCH. SCI. 56 (2005).

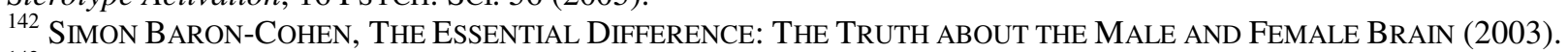

${ }^{143} I d$. at 61 .

${ }^{144} I d$. at 21 .
} 
that women were more risk averse than men), but the consequences of his claims if we took the logic of Roper would be absurd. Men would be excused and be less culpable for their violent crimes; after all their minds are not empathetic and they take more risks than women. Women, on the other hand, would be condemned severely for their violence. The battered women syndrome defense would be turned upside down on its head!

Curiously none of these medical findings regarding adult criminals have had much success as an insanity defense. ${ }^{145}$ The law has strongly resisted the ever-growing DSM list of mental diseases as a basis for acquittals. Yet, for juveniles, the Supreme Court seemed willing to dispense with years of practice on the basis of recently imaged brains that do not lead to any consistent or sensible policy implications.

Medical researchers would all agree that environmental factors could be relevant for individuals who may have a genetic pre-disposition to contract cancer or diabetes. ${ }^{146}$ While someone may have a family history of diabetes and cancer, thereby increasing the odds of contracting one of these two diseases, doctors routinely advises us to use our diet as a preventative measure. Were someone to have diabetic parents, surely the advice would be to avoid fats and sugars. Now consider if such an individual, instead, consumed copious quantities of sweets every day and ignored his weight. We would almost lay blame with the individual if he contracted diabetes. No one would pity such an individual. The fact that he had a genetic predisposition for diabetes means that the imperative to avoid an unhealthy diet is even higher. ${ }^{147}$

\footnotetext{
${ }^{145}$ A good (but dated) survey of the insanity defense and the reluctance of the law to adopt the latest medical evidence is MichaEL L. PERLIN, THE JURISPRUDENCE OF THE INSANITY DEFENSE (1994).

${ }^{146}$ Alice H. Lichtenstein \& Robert M. Russell, Essential Nutrients: Food or Supplement? Where should the Emphasis be? 294 J. Am. Med. Ass'n 351 (2005) (citing 125 studies that have looked at the impact of diet on disease).

${ }^{147}$ An excellent discourse on how genetic and environmental determinism is complemented by self-determinism by all organisms, see STEVEN Rose, LIFELINES: LIFE BEYOND THE GENE (2003); LIFELINES: BIOLOGY BEYOND DETERMINISM (1997); GISELA KAPLAN \& LESLEY J. ROGERS, GENE WORSHIP: MOVING BEYOND THE
} 
Recall that the researchers, who claimed to have found medical reasons for violence, also conceded that environmental factors contributed to the incidence of violence. ${ }^{148}$ And just as no one would sympathize with the sugar-consuming diabetic, we should not allow the medicalization of juvenile behavior to take away the culpability of those who engage in crime. The sugar-consuming diabetic should be admonished for being reckless, and so should juveniles whose recklessness leads them to murder and other crimes.

The medical profession, like any other profession, seeks to maximize its influence over society in order to maximize its returns to its members. This statement should not be controversial, and is consistent with the theory of special interest groups. ${ }^{149}$ The medical profession, in an attempt to gain more importance for itself, has seen medical issues in entirely new areas. Gun control, for example, has been claimed as a subject that doctors see fit to comment on. ${ }^{150}$ It is not surprising, therefore, to see the AMA wade into the question of juvenile executions. In its quest to gain dominion over more American's lives, the National Institute for Mental Health now claims that almost half of Americans are or will become mentally ill. ${ }^{151}$ Listing such diseases as female sexual disorder and passive-aggressive disorder as mental illnesses, it is a wonder that we are all not culpable for our crimes.

It is unfortunate that the majority (and the minority) did not take a skeptical look at the amici briefs. Had economists presented their empirical findings in a brief, the majority would Nature/Nurture Debate over Genes, Brain, AND Gender (2003); Richard C. Lewontin, Biology As IDEOLOGY: THE DOCTRINE OF DNA (1993)

${ }^{148}$ See e.g. supra notes $137 \& 138$.

${ }^{149}$ The economist Mancur Olson provided great insights into how special interest groups can impose their agenda on the public. Mancur Olson, Logic of Collective Action: Public Goods AND the TheOry OF Groups (1965); The Rise and DeCline of Nations: Economic Growth, STAGFlation, AND Social Rigidities (1984). See also ${ }^{150}$ See e.g. David C. Grossman et. al, Gun Storage Practices and Risk of Youth Suicide and Unintentional Firearm Injuries, 293 J. AM. MED. Ass'N 707 (2005); Garen J. Wintemute et. al, Subsequent Criminal Activity Among Violent Misdemeanants Who Seek to Purchase Handguns: Risk Factors and Effectiveness of Denying Handgun Purchase, 285 J. AM. MED. ASs'N 1019 (2001). For a critique of the American Medical Association's gun control politics, see Miguel A. Faria, Jr., Medical Warrior: Fighting Corporate Socialized Medicine (1997). ${ }^{151}$ Are Half of All Americans Mentally Ill?, August 13, 2005 avlaible at http://www.foxnews.com/story/0,2933,165646,00.html [find permanent cite when available]. 
have been forced to ask the hard question of whether the science behind the AMA is even valid in the first place. All that the studies show is that there are some medical patterns associated with juveniles' brains, but no concrete causal relationships have been established. ${ }^{152}$

The science of mental diagnoses is ephemeral and volatile. The medical profession has also taken contradictory positions over the years. The DSM manual, that Justice Kennedy relied on, once classified homosexuality as a mental disease, ${ }^{153}$ and it was once believed that masturbation caused schizophrenia. ${ }^{154}$ It is curious how the science justifying including it in a medical manual changed so dramatically in a span of few years that it was completely removed from the next edition of DSM. If this is the pace of scientific progress, then what faith can we have in the science behind the AMA's brief? Is this science the sort of foundation the Supreme Court should rest its legal conclusions upon? These legal conclusions now bind the nation and the states and have removed a valuable instrument from law enforcement. Juvenile executions were the norm in this nation for over two centuries, and the Supreme Court should have demanded higher levels of proof when condemning the practice.

It is not surprising, however, to see the Supreme Court's ruling in Roper. Our society has been moving away from the days when children were charged with responsibilities and had few

\footnotetext{
${ }^{152}$ Mary Beckman, Crime, Culpability, and the Adolescent Brain, 305 SCIENCE 596, 599 (2004) Although many researchers agree that the brain, especially the frontal lobe, continues to develop well into teenhood and beyond, many scientists hesitate to weigh in on the legal debate. Some, like Giedd, say the data "just aren't there" for them to confidently testify to the moral or legal culpability of adolescents in court. Neuroscientist Elizabeth Sowell of UCLA says that too little data exist to connect behavior to brain structure, and imaging is far from being diagnostic. "We couldn't do a scan on a kid and decide if they should be tried as an adult," she says.

See also Michael McGough, 'My Brain Made Me Do It'; What Happens to Guilt and Innocence When an MRI can Tell You who is Likely to Commit a Violent Crime?, PITT. PosT-GAZ., June 6, 2005, at B7 (quoting Professor Stephen J. Morse, a professor of law and psychology at the University of Pennsylvania, who stated that "we have no idea how the brain enables the mind").

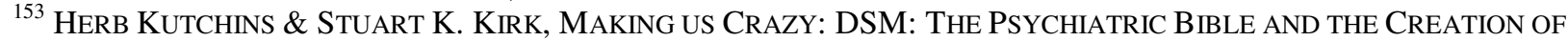
MENTAL Disorders 55 (1997). See also Bias In PSYChiATRIC Diagnosis (Paula J. Caplan \& Lisa Cosgrove eds., 2004) (demonstrating that many of psychiatric diagnoses in DSM are marred by race, age, income, and other biases). ${ }^{154}$ E. FULlER TORREY, SURVIVING SCHIZOPHRENIA: A MANUAL FOR FAMILIES, CONSUMERS, AND PROVIDERS 168 (2001).
} 
privileges. Today the opposite holds: they are free to commit crime with small consequences, but can have an abortion on demand just as an adult. At the founding of this nation, it was not uncommon for men under twenty to have started their careers. Consider the following founding fathers. Elbridge Gerry graduated from Harvard at age 18 and then joined his father's business. ${ }^{155}$ Caleb Strong was nineteen when he graduated from Harvard and started his career. ${ }^{156}$ Roger Sherman was forced by his father's death to start his career at age twenty. ${ }^{157}$ William Samuel Johnson earned his B.A. at seventeen and his M.A. at twenty, and was a member of the bar at twenty-two. ${ }^{158}$ Alexander Hamilton enrolled at King's College (now Columbia University) at age sixteen, but left for service in the military in 1776 at the age of nineteen. ${ }^{159}$ Robert Yates was twenty-two when admitted to the bar, ${ }^{160}$ and John Lansing was only twenty-one. ${ }^{161}$ Jonathan Dayton who was the youngest of the framers of the Constitution, was only sixteen when graduated from the College of New Jersey, and was captain in the Continental army by the age of nineteen. ${ }^{162}$ Benjamin Franklin apprenticed with his father at the age of ten, only to go on at age twelve and learn the printer's trade. ${ }^{163}$ He started as a printer on his own at age seventeen and traveled to London where also worked as printer at eighteen. While he is remembered today as a man of letters and science, the chronology of his childhood should indicate that he never had any formal education; he was self-taught. ${ }^{164}$ Robert Morris

\footnotetext{
${ }^{155}$ M.E. BRADFORD, FOUNDING FATHERS: BRIEF LIVES OF THE FRAMERS OF THE UNITED STATES CONSTITUTION 6 (1994).

${ }^{156}$ Id. at 12.

${ }^{157} I d$. at 21 .

${ }^{158} I d$. at 30 .

${ }^{159} I d$. at $40-41$.

${ }^{160} \mathrm{Id}$. at 49.

${ }^{161} \mathrm{Id}$. at 51.

${ }^{162} \mathrm{Id}$. at 61-61.

${ }^{163} \mathrm{Id}$. at 65.

${ }^{164} \mathrm{Id}$. at 65.
} 
apprenticed in his early teens at a countinghouse, ${ }^{165}$ while Luther Martin was eighteen when he graduated from the College of New Jersey after four years of college and two years of grammar school before that. ${ }^{166}$ Even in England at the time, William Pitt the Younger became Prime Minister at age twenty-four, ${ }^{167}$ the same age George Mason became a judge in Fairfax County, Virginia $^{168}$ and Charles Dickens wrote The Pickwick Papers. ${ }^{169}$

It was only in the nineteenth century that juveniles began to receive special and lenient treatment as members of society and as criminals. ${ }^{170}$ Slowly over time corporal punishments for all disappeared, and the emphasis shifted to reform and rehabilitation especially for youth. Somewhere in that process, American society began to lose its focus on accountability. Our children are no longer the shining lights our founding fathers once were. ${ }^{171}$ We have become a nation of victims, ${ }^{172}$ so claims one author, where we are no longer responsible for our lack of professionalism or for our crimes. We all seem to be victims in need of therapy and self-esteem,

\footnotetext{
165 Id. at 95 .

${ }^{166} I d$. at 111 .

${ }^{167}$ William Hague, William PitT THE Younger (2005).

${ }^{168}$ BRADFORD, supra note 155 at 149 . The average age of those entering universities in the $14^{\text {th }}$ century was between fifteen and seventeen, and it seems from the ages of the founding fathers' graduation that stayed the same even in eighteenth century America. HIBBERT, supra note 122, at 135. For a good study of how youth in America were always at the forefront of society until very recently, see GLEN WALLACH, OBEDIENT SONS: THE DISCOURSE OF YOUTH AND GENERATIONS IN AMERICAN CULTURE 1630-1860 (1997).

169 John Marshall Gest, The LAWYER IN LITERATURE 6 (Wm. W. Gaunt \& Sons, Inc. 1982) (1913).

${ }^{170}$ For more details on the youth justice system and its history, see DEAN J. CHAMPION, THE JUVENILE JUSTICE SySTEM: DELINQUENCY, PROCESSING, AND THE LAW (2001); JoHn R. SuTTON, STUBbORn CHILDREN: CONTROLling DELINQUENCY IN THE UNITED STATES 1640-1981 (1988); ROBERT M. MENNEL, THORNS \& THISTLES: JUVENILE DELINQUENTS IN THE UNITED STATES 1825-1940 (1973); JOSEPH M. HAWES, CHILDREN IN URBAN

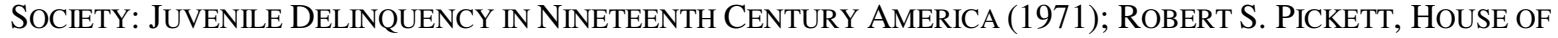
REFUGE: ORIGINS OF JUVENILE REFORM IN NEW YORK STATE, 1815-1857 (1969); FREDRICK J. LUDWIG, YOUTH AND THE LAW: HANDBOOK OF LAW AFFECTING YOUTH (1955). For a history of juveniles in Britain and Europe, see BECOMING DELINQUENT: BRITISH AND EUROPEAN YOUTH, 1650-1950 (Pamela Cox \& Heather Shore eds., 2002); HeAther Shore, ArTFul Dodgers : Youth AND Crime In EARLY NinETEENTH-CENTURY LONDON (1999).

${ }^{171}$ For an analysis of how America's children are failing academically, see CHARLES J. SYKES, DUMBING DOWN OUR KIDS: WhY AMERICA's CHILDREN FEEL GOOD ABOUT THEMSELVES BUT CAN'T READ, WRITE, OR ADD (1995). ${ }^{172}$ Charles J. SyKes, A NATiOn OF Victims (1992). See also JaMES Q. Wilson, Moral JudgMENT: DoEs the Abuse EXCUSE THREATEN OUR LEGAL SYSTEM (1997).
} 
with no corresponding increase in accountability, professionalism, or industry. ${ }^{173}$ It is no surprise that the Supreme Court also bought into this culture of victimhood and abolished the death penalty for juveniles. It seems only a matter of time, before it does the same for adults. ${ }^{174}$

What is needed, therefore, is a return to first principles where only the ability to distinguish between right and wrong is the criteria by which individuals are culpable. Medical evidence should be used for what medicine is best suited for, namely, treatment. To use medical evidence as a basis for legal decisions is no more legitimate than to use economic evidence, and to disturb well settled legal principles should require a far more principled approach than the latest MRI images from a laboratory.

\section{Conclusion}

If indeed juveniles are as portrayed in Roper, reckless voracious consumers of the present who have little fear of punishment because of their underdeveloped brains, then the answer is higher and more severe punishment for juveniles. The empirical evidence, though, suggests that juveniles are just as rational as adults, and this may mean that at best juveniles should be treated just like adults, no harsher and no more lenient. While there may be legitimate reasons for abolishing the death penalty for juveniles specifically or even the death penalty in general, the reasons given by the Supreme Court in Roper were neither cogent nor convincing. Hopefully, the Supreme Court will re-visit the issue and restore to the states that valuable tool that they need to combat the youth and their violent crimes.

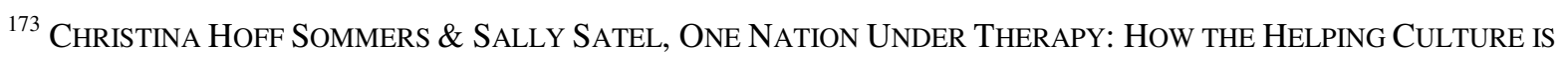
ERODING SELF-RELIANCE (2005).

${ }^{174}$ Justice Stevens' concurring opinion in Roper seemed to suggest that because of the "evolving standards of decency", one day the Court might abolish the death penalty. Roper, 125 S.Ct. 1183, 1205 (Stevens, J. concurring). Recent comments by Justice Stevens reinforce my view of his comments. Editorial, Justice Right to Worry about Death Penalty: John Paul Stevens, Addressing the American Bar Association, Takes Note of Improper Verdicts and Urges Caution on Use of Capital Punishment, DENVER POST, August 9, 2005, at B06.
} 


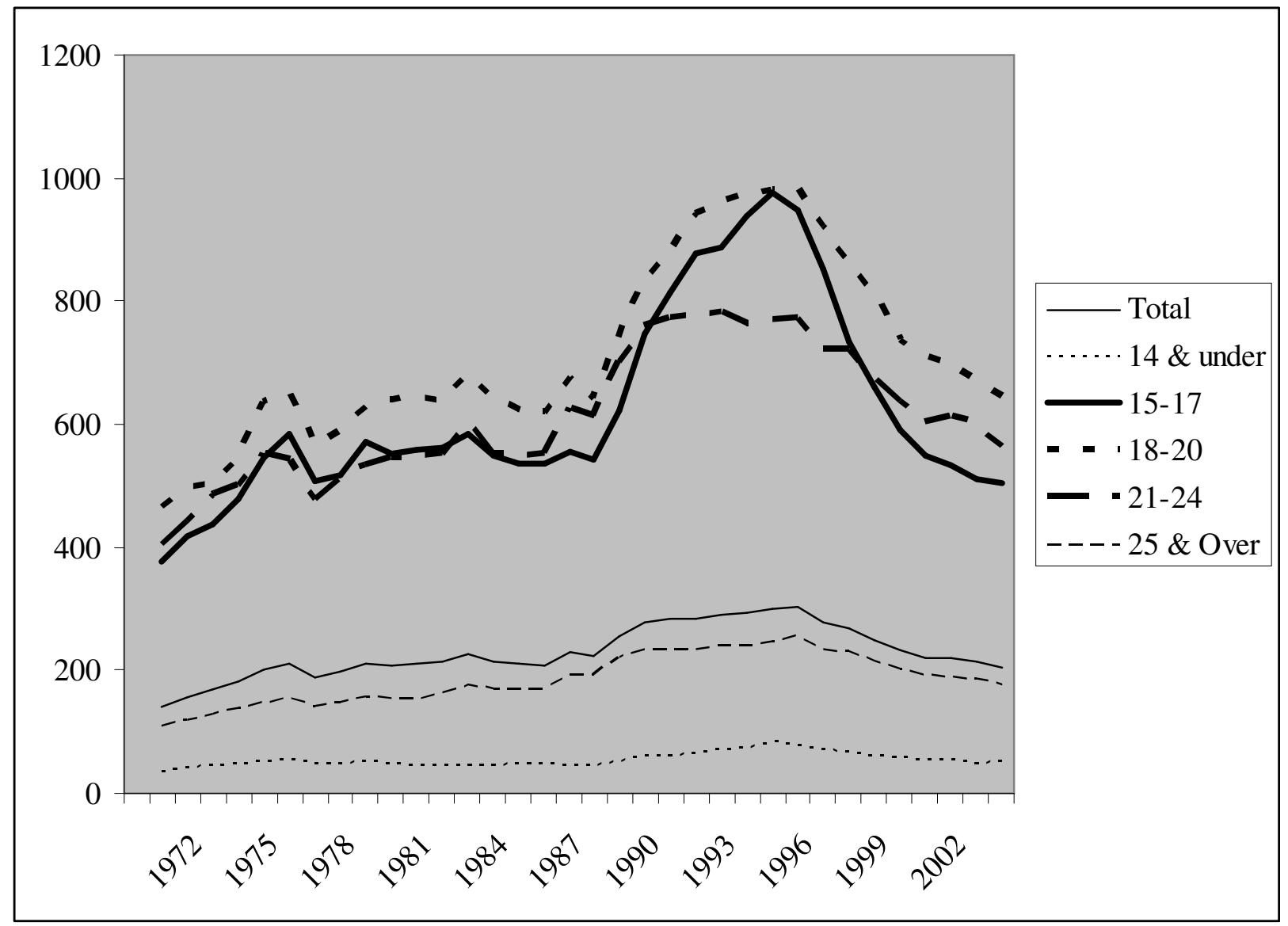

Figure 1: Arrest Rates for Violent Crimes by Age Group

Source: Bureau of Justice Statistics (http://www.ojp.usdoj.gov/bjs/crimoff.htm\#data) 


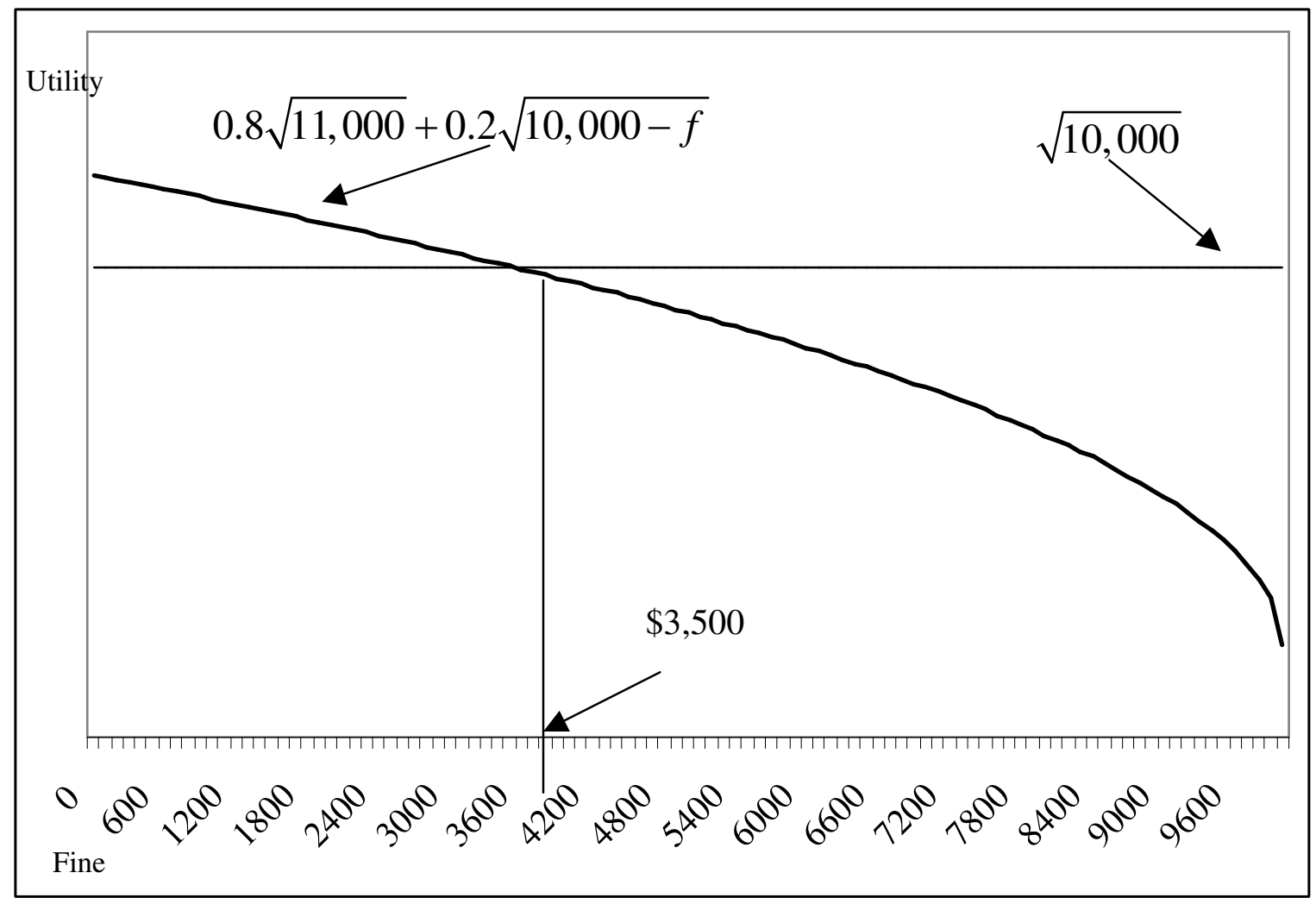

Figure 2

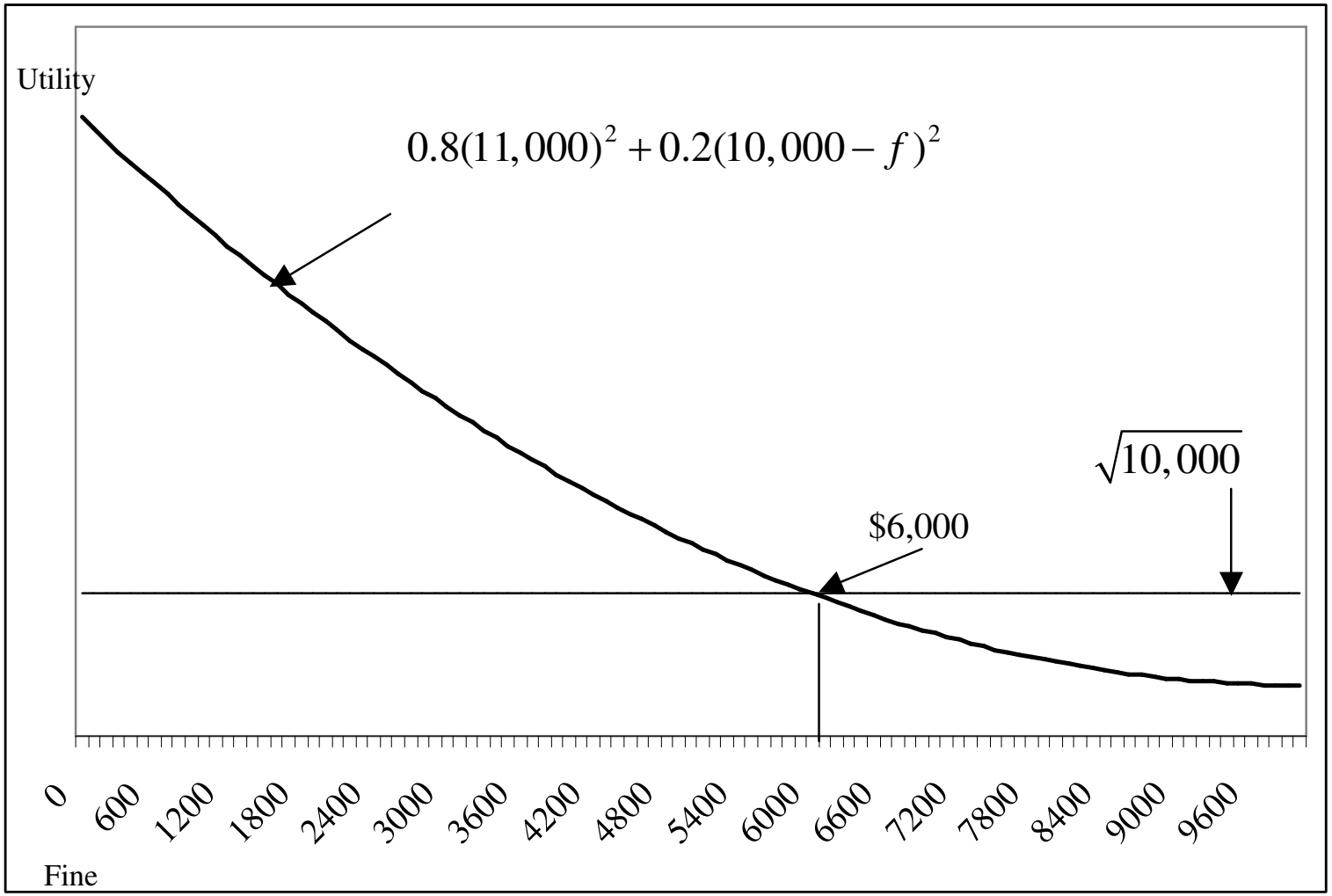

Figure 3 


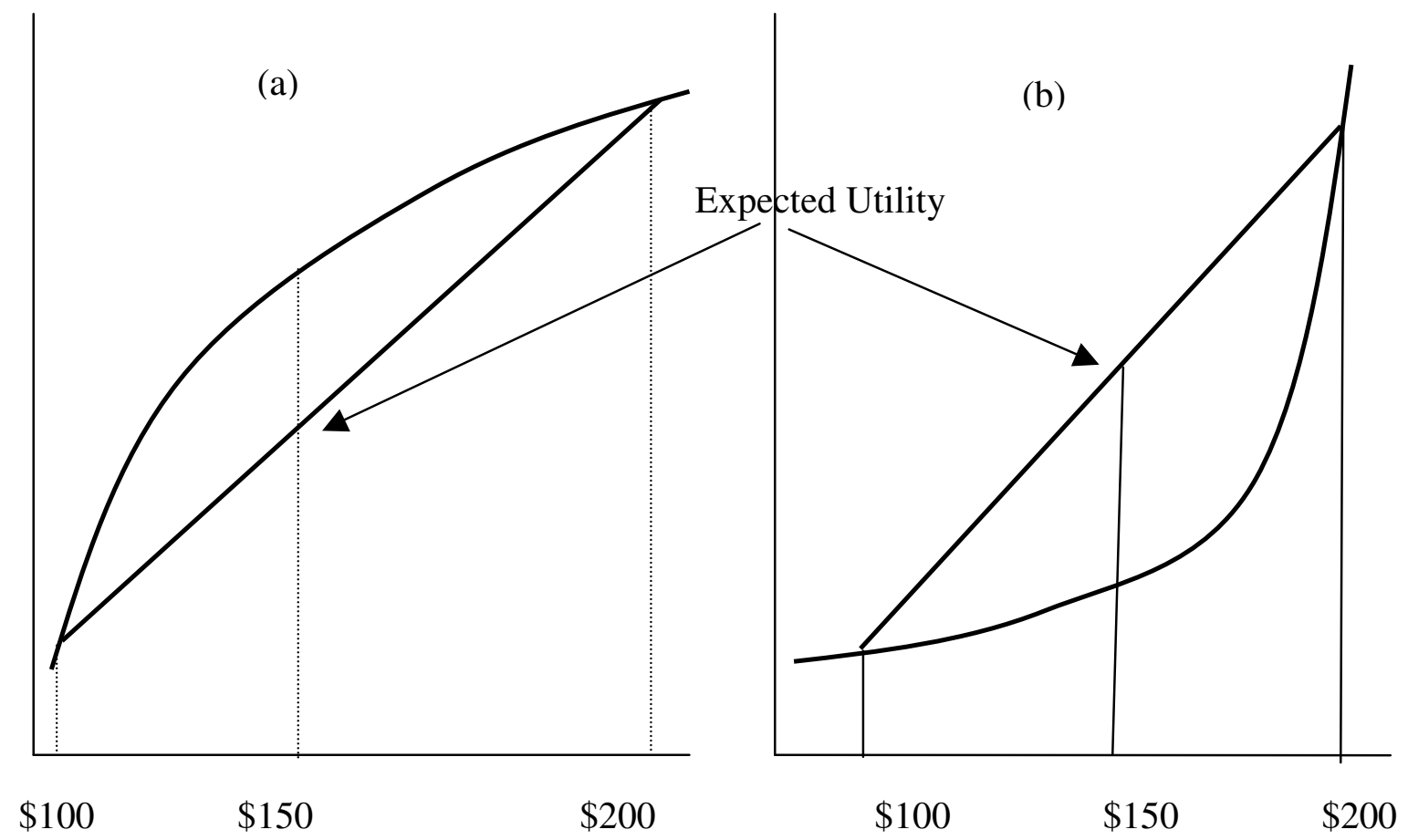

Figure 5

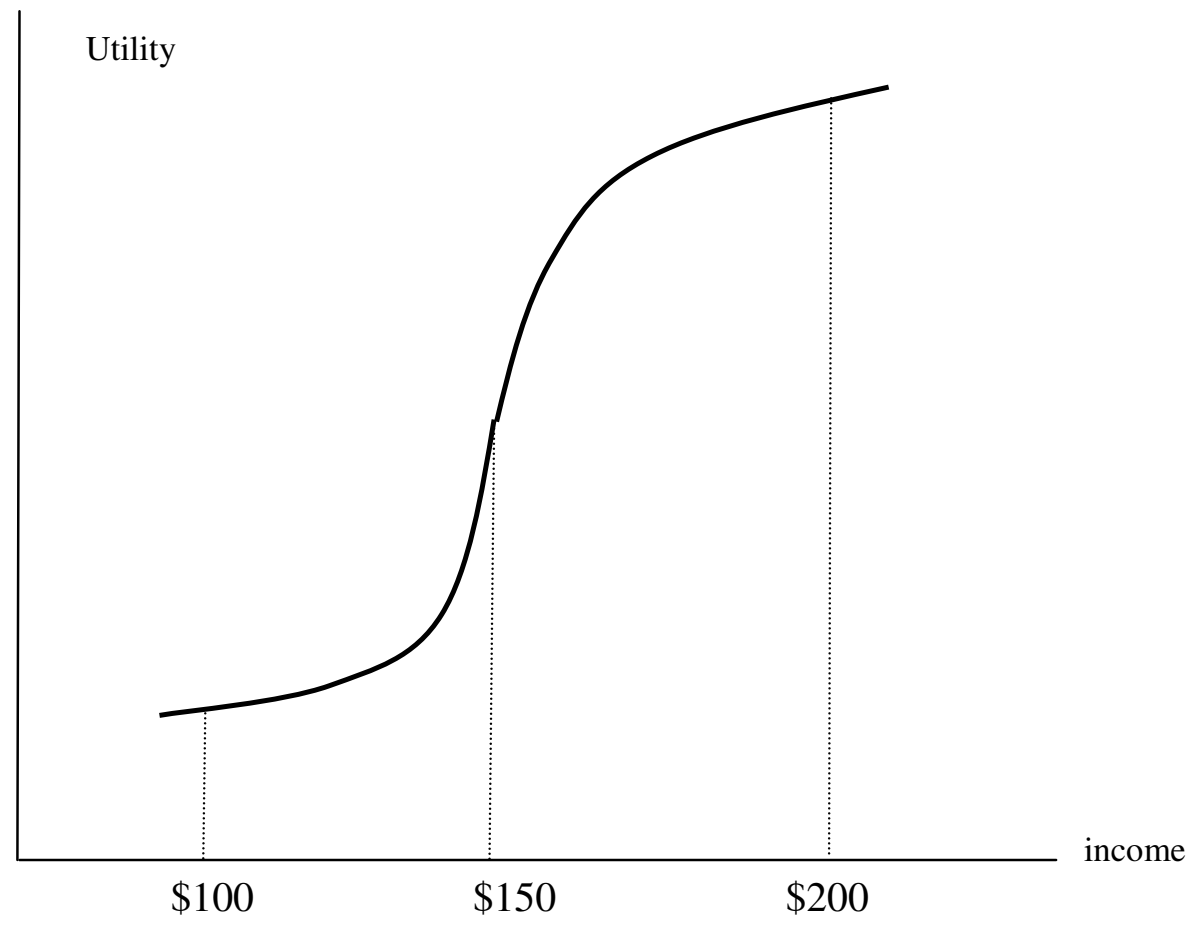


Figure 6

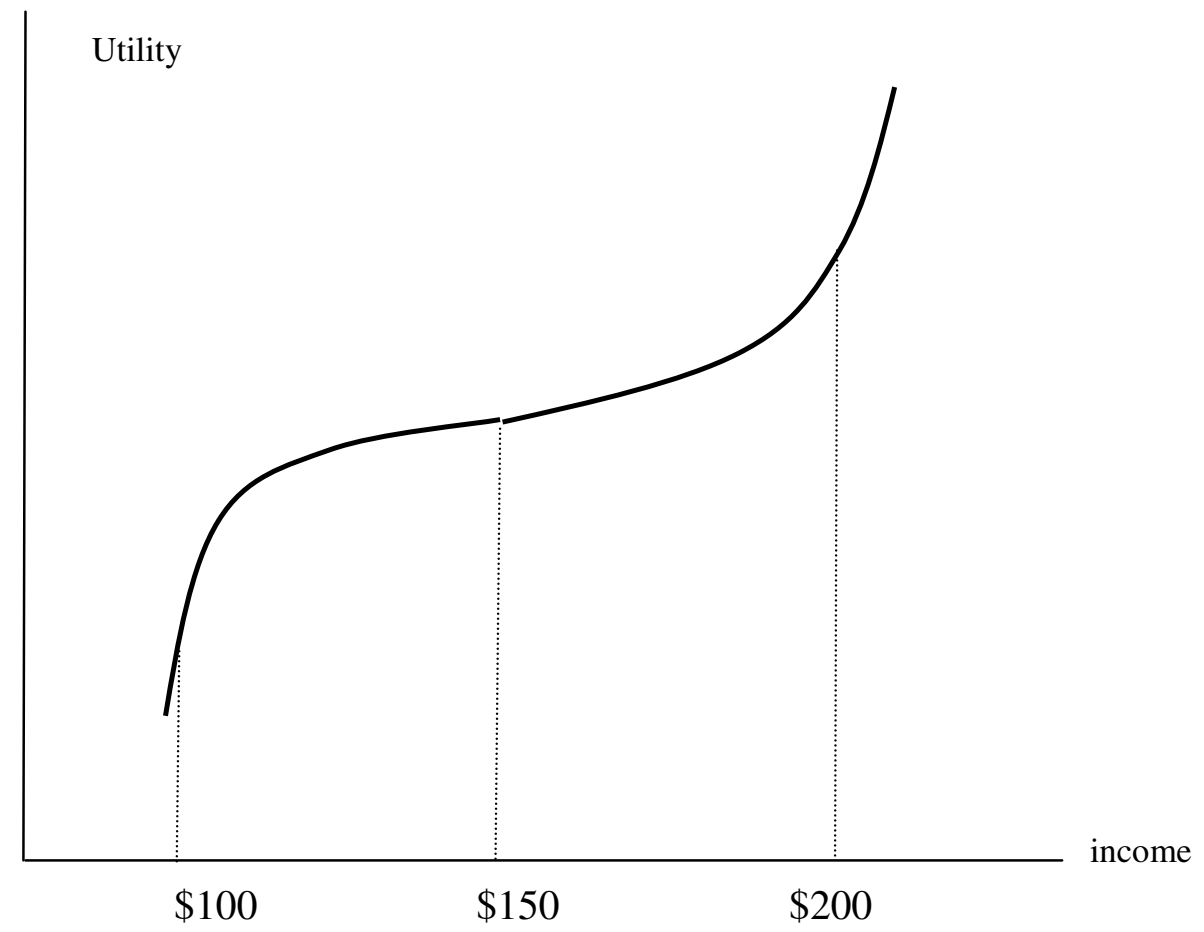

Figure 7

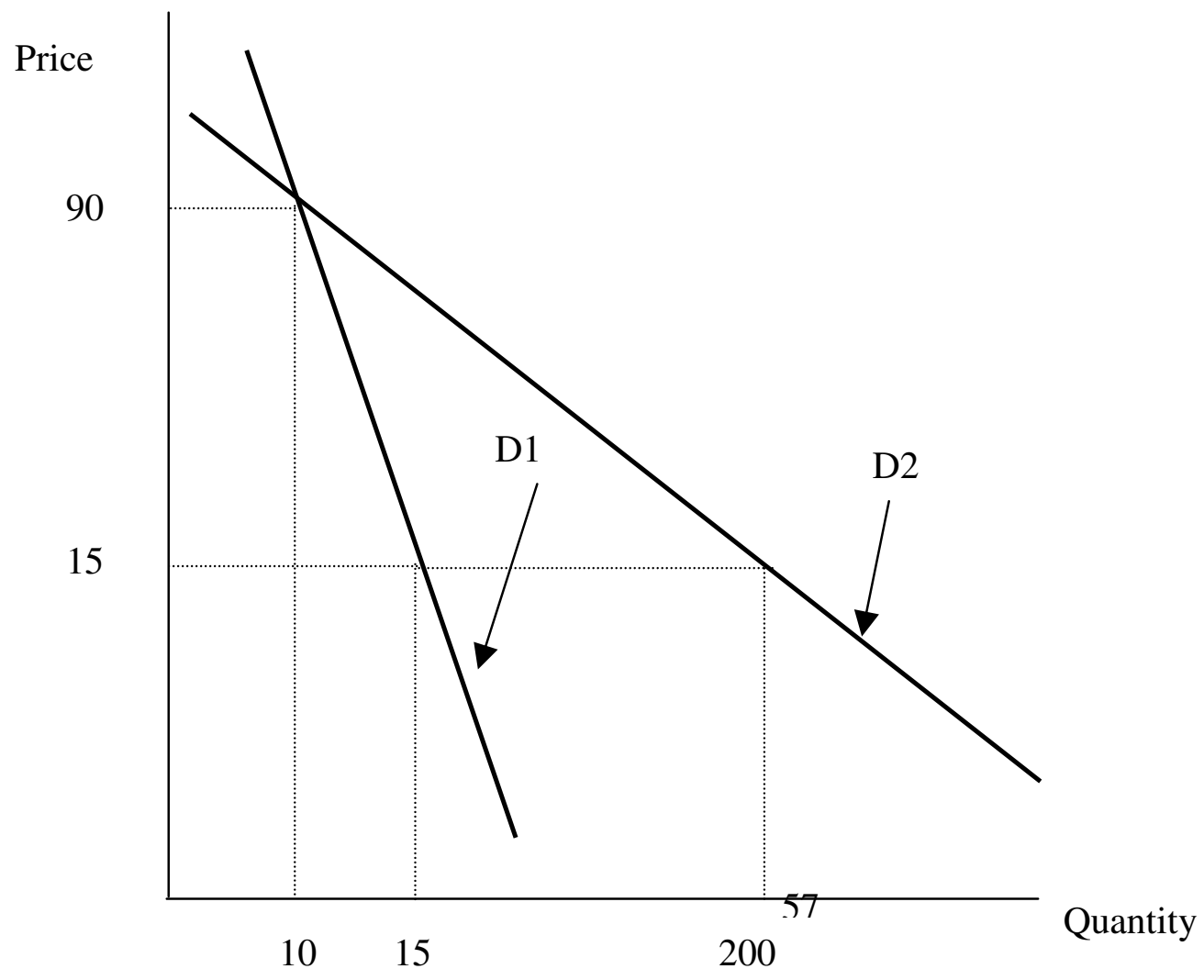

Figure 4 